\title{
Size distributions of dicarboxylic acids, ketoacids, $\alpha$-dicarbonyls, sugars, WSOC, OC, EC and inorganic ions in atmospheric particles over Northern Japan: implication for long-range transport of Siberian biomass burning and East Asian polluted aerosols
}

\author{
S. Agarwal ${ }^{1}$, S. G. Aggarwal ${ }^{1,2}$, K. Okuzawa ${ }^{1, *}$, and K. Kawamura ${ }^{1}$ \\ ${ }^{1}$ Institute of Low Temperature Science, Hokkaido University, Kita 19, Nishi 8, Sapporo - 0600819, Japan \\ ${ }^{2}$ National Physical Laboratory (Council of Scientific and Industrial Research), Dr. K.S. Krishnan Road, \\ New Delhi - 110012, India \\ *now at: Japan Isotope Analysis Laboratory, Inc., 75-1 Onocho, Tsurumi-ku, Yokohama-city, Kanagawa 230-0046, Japan
}

Received: 25 February 2010 - Published in Atmos. Chem. Phys. Discuss.: 10 March 2010

Revised: 18 June 2010 - Accepted: 18 June 2010 - Published: 2 July 2010

\begin{abstract}
To better understand the size-segregated chemical composition of aged organic aerosols in the western North Pacific rim, day- and night-time aerosol samples were collected in Sapporo, Japan during summer 2005 using an Andersen impactor sampler with 5 size bins: $D_{p}<1.1,1.1-2.0$, 2.0-3.3, 3.3-7.0, >7.0 $\mu \mathrm{m}$. Samples were analyzed for the molecular composition of dicarboxylic acids, ketoacids, $\alpha$ dicarbonyls, and sugars, together with water-soluble organic carbon (WSOC), organic carbon (OC), elemental carbon (EC) and inorganic ions. Based on the analyses of backward trajectories and chemical tracers, we found that during the campaign, air masses arrived from Siberia (a biomass burning source region) on 8-9 August, from China (an anthropogenic source region) on 9-10 August, and from the East China Sea/Sea of Japan (a mixed source receptor region) on 10-11 August. Most of the diacids, ketoacids, dicarbonyls, levoglucosan, WSOC, and inorganic ions (i.e., $\mathrm{SO}_{4}^{2-}, \mathrm{NH}_{4}^{+}$ and $\mathrm{K}^{+}$) were enriched in fine particles $\left(\mathrm{PM}_{1.1}\right)$ whereas $\mathrm{Ca}^{2+}, \mathrm{Mg}^{2+}$ and $\mathrm{Cl}^{-}$peaked in coarse sizes $(>1.1 \mu \mathrm{m})$. Interestingly, OC, most sugar compounds and $\mathrm{NO}_{3}^{-}$showed bimodal distributions in fine and coarse modes. In $\mathrm{PM}_{1.1}$, diacids in biomass burning-influenced aerosols transported from Siberia (mean: $252 \mathrm{ng} \mathrm{m}^{-3}$ ) were more abundant than those in the aerosols originating from China $\left(209 \mathrm{ng} \mathrm{m}^{-3}\right)$ and ocean $\left(142 \mathrm{ng} \mathrm{m}^{-3}\right)$, whereas $\mathrm{SO}_{4}^{2-}$ concentrations were
\end{abstract}

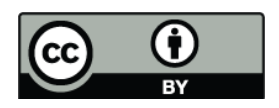

Correspondence to: K. Kawamura (kawamura@lowtem.hokudai.ac.jp) highest in the aerosols from China (mean: $3970 \mathrm{ng} \mathrm{m}^{-3}$ ) followed by marine- $\left(2950 \mathrm{ng} \mathrm{m}^{-3}\right)$ and biomass burninginfluenced $\left(1980 \mathrm{ng} \mathrm{m}^{-3}\right)$ aerosols. Higher loadings of WSOC (2430 $\left.\mathrm{ng} \mathrm{m}^{-3}\right)$ and OC (4360 $\mathrm{ng} \mathrm{m}^{-3}$ ) were found in the fine mode, where biomass-burning products such as levoglucosan are abundant. This paper presents a case study of long-range transported aerosols illustrating that biomass burning episodes in the Siberian region have a significant influence on the chemical composition of carbonaceous aerosols in the western North Pacific rim.

\section{Introduction}

Tropospheric aerosols contain a significant quantity of organic components, which account for 10-70\% of total fine aerosol mass (Jacobson et al., 2000; Kanakidou et al., 2005). Important sources recognized for organic aerosols are primary emissions from biomass burning and bio- and fossilfuel combustions as well as secondary productions from biogenic and anthropogenic emissions (Claeys et al., 2004; Koch et al., 2007; Schichtel et al., 2008; Venkataraman et al., 2005; Wang et al., 2006a). Loadings of organic and inorganic aerosols are significantly influenced by biomass burning and other anthropogenic sources (Mochida et al., 2003; Wang et al., 2006a; Warneke et al., 2009). The changes in the chemical composition can alter the optical and microphysical properties of aerosol particles (Reid et al., 1998).

Published by Copernicus Publications on behalf of the European Geosciences Union. 
The Asian continent is one of the most important source regions for the emissions of natural dusts, pollutants and biomass burning aerosols on a global scale (Mochida et al., 2003; Simoneit et al., 2004a, b), which are long-range transported to the remote Pacific Ocean and North America (Brock et al., 2004). Therefore, the Asian aerosols have a potential impact on atmospheric chemistry and global climate forcing (Clarke et al., 2004; Huebert et al., 2003). The western North Pacific rim is a receptor region for anthropogenic and mineral dust aerosols originating from the Asian continent. Studies on aerosol characteristics in the western Pacific rim is of great importance to better understand the climate consequences linked with chemical and physical properties of the Asian aerosols over the Pacific region.

Biomass burning events in Siberia and South Asia mostly occur in late spring to summer (Warneke et al., 2009). During this period, dust episodes in Mongolian desert and loess regions of East Asia also contribute to the increased aerosol burden in the Pacific region (Clarke et al., 2004). In fact, on the pathways of Siberian biomass emissions toward North East Asia, dusts from Mongolian desert and loess regions provide an alkaline surface that uptakes acidic gases (Krueger et al., 2004), adding more complexity to the Asian aerosols. Therefore, chemical compositions of aerosols influenced by these events are important to better understand their atmospheric processing during a long-range transport in the western North Pacific rim.

Dicarboxylic acids and sugars are two major compound classes that significantly contribute to water-soluble organic carbon (WSOC) in aerosol particles (Simoneit et al., 2004a, b; Wang et al., 2006b). In the ambient aerosols, dicarboxylic acids are mainly produced by photochemical processes (Kawamura and Yasui, 2005) of the precursor species from different sources, such as biomass burning, vehicular exhaust, etc., while saccharidic compounds are originated from fungal spores and plant material. More precisely, arabitol, mannitol and trehalose are characteristic for fungal spores (Lewis and Smith, 1967; Bieleski, 1982), while monosaccharides such as fructose, glucose and inositol are characteristic for plant material such as pollen, fruit, and fragments (Bartolozzi et al., 1997; Baker et al., 1998; Pacini, 2000). Soil dust probably contains fungal spores, and plant pollen and debris, while biomass burning of plant material may also release substantial amounts of sugar compounds (such as levoglucosan) in aerosol particles (Simoneit et al., 2004a, b).

Therefore, their characterizations on the molecular level can further strengthen our understanding on Asian outflows of aerosols. Some studies have been conducted in several Japanese Islands (especially the southern area of the western Pacific rim) with a focus on the seasonal and temporal variations of Asian outflows (Clarke et al., 2004; Huebert et al., 2003, and references therein). However, the size distributions of organic aerosols at molecular level are rarely studied (Mochida et al., 2007). This information is important be- cause it allows one to gain useful information on the sources and atmospheric processing of Asian aerosols.

In our previous paper, Aggarwal and Kawamura (2009) discussed the aging of WSOC fraction in total suspended particles (TSP) collected in Sapporo (northern Japan). In that study, we found that although organic carbon (OC) loadings in aerosols may depend on sources, WSOC/OC ratios increased with the photochemical aging of aerosols. The increase in WSOC/OC ratios has been interpreted by a photochemical transformation of primary organic aerosols to WSOC and/or a formation of water-soluble secondary organic aerosol (SOA) via gas-to-particle conversion during long-range atmospheric transport. Although the sizesegregated chemical compositions have not been studied in Sapporo (Aggarwal and Kawamura, 2009), such studies should provide helpful information to better understand atmospheric transformation processes.

In this study, we collected size-segregated aerosols in Sapporo, the western Pacific rim during summer on day- and night-time basis. Here, we analyzed the size-segregated aerosol samples for low molecular weight dicarboxylic acids, ketoacids, $\alpha$-dicarbonyls, and sugar compound classes as well as WSOC, OC, EC and major ions. Using air mass backward trajectory combined with tracer analyses, we found that 3 types of aged aerosols were sampled during the campaign with an influence of biomass burning in Siberia, polluted aerosols from China, and marine + mixed source aerosols from the East China Sea/Sea of Japan. Here we report the size distributions of organic and inorganic species and discuss the influence of Siberian biomass burning and Chinese pollution episodes on the loading of organic aerosols in northern Japan. This size-segregated aerosol sampling followed by chemical analyses makes it possible to better discuss the atmospheric processing of water-soluble organic species.

\section{Experimental}

\subsection{Aerosol sampling}

The city of Sapporo (location: $43^{\circ} 3^{\prime} 56^{\prime \prime} \mathrm{N}$ and $141^{\circ} 21^{\prime} 27^{\prime \prime} \mathrm{E}$, population: 1.9 million) is located in the western part of Hokkaido, the northernmost major island of Japan (see Fig. 1 in Aggarwal and Kawamura, 2009). It is a good location for collecting the long-range transported atmospheric particles from Siberia (Russia), China and surrounding seas (including the Sea of Japan and western North Pacific). Aerosol particles were segregated using an Andersen high-volume impactor sampler with 50\% cutoff diameters of 1.1, 2.0, 3.3 and $7.0 \mu \mathrm{m}$ (i.e., with 5 size bins: <1.1, 1.1-2.0, 2.0-3.3, $3.3-7.0,>7.0 \mu \mathrm{m}$; hereafter we discuss the size distribution considering these 5 size bins). Particles were collected on pre-combusted (at $450{ }^{\circ} \mathrm{C}$ for $\left.6 \mathrm{~h}\right)$ quartz filters $(30 \mathrm{~cm}$ diameter) and a backup quartz filter $(20 \times 25 \mathrm{~cm})$ at a flow rate 
of $\sim 5661 \mathrm{~min}^{-1}$. Six sets of aerosol samples (and one set of field blank) were collected on the rooftop of our institute building ( $\sim 15 \mathrm{~m}$ a.g.l.) at Hokkaido University. The samples were collected from 8-11 August on day- and nighttime basis. Day-time samples were collected between 04:30 to $18: 30 \mathrm{~h}$ (local time, LT) whereas night-time samples were 19:30 to $03: 30 \mathrm{~h}$ (LT). The filter samples were stored in a clean glass jar (pre-combusted) with a Teflon-lined screw cap at $-20^{\circ} \mathrm{C}$ prior to analysis.

\subsection{Chemical analyses}

Water-soluble dicarboxylic acids, ketocarboxylic acids and $\alpha$-dicarbonyls in the aerosol filter samples were determined by the methods described elsewhere (Kawamura, 1993; Kawamura and Ikushima, 1993). Briefly, a part of the filter (one eighth of the Andersen filter, and $\sim 5 \mathrm{~cm}^{2}$ of backup filter) was cut off, and extracted with Milli-Q water (12-15 ml) using an ultrasonic bath $(3 \times 10 \mathrm{~min})$. Organic acids and carbonyls in the extracts were derivatized to esters and acetals with $14 \% \mathrm{BF}_{3}$ in $\mathrm{n}$-butanol, respectively. The derivatives were determined using a capillary gas chromatograph (GC) with a flame ionization detector (FID). Recoveries of diacids in the analytical procedure were $\sim 80 \%$ for oxalic acid and better than $80 \%$ for other species. The analytical errors (repeatability) in the determination of diacids were within $6 \%$ for major diacids based on duplicate analysis.

On the other hand, sugars were extracted from another aliquot of filter cut with a dichloromethane and methanol mixture (2:1), derivatized with N,O-bis-(trimethylsilyl) trifluoroacetamide (BSTFA) (containing $1 \%$ trimethylsilyl chloride) and pyridine as catalyst, and determined using a GC/mass spectrometry (GC/MS) (Wang et al., 2006b). Recoveries of all sugar compounds determined during the analytical procedure were $>90 \%$, while the analytical errors (repeatability) were within $10 \%$ based on duplicate analysis.

For the measurement of water-soluble organic carbon (WSOC) and inorganic ions, an aliquot of filter (one eighth of the Andersen filter and $\sim 5 \mathrm{~cm}^{2}$ of backup filter) was extracted with organic-free Milli-Q water $(>18 \mathrm{M} \Omega \mathrm{cm}, 15 \mathrm{ml})$ using an ultrasonic bath for $30 \mathrm{~min}$. Particles in the extracts were removed by filtration with quartz wool and then a membrane disc filter (Millex-GV, Millipore, $0.22 \mu \mathrm{m}$ ). For the determination of WSOC, $0.1 \mathrm{ml}$ of $2 \mathrm{M} \mathrm{HCl}$ was added to $5 \mathrm{ml}$ water extracts. After purging $10 \mathrm{~min}$ with ultra pure air $\left(80 \mathrm{ml} \mathrm{min}^{-1}\right), 100 \mu \mathrm{l}$ of solution were injected into a TOC analyzer (Shimadzu TOC-5000A) (Wang et al., 2005). An analytical error (repeatability) was estimated to be within $6 \%$ by the duplicate analyses.

Another aliquot of water extracts $(\sim 7 \mathrm{ml})$ was used for the determination of major ions (i.e., $\mathrm{SO}_{4}^{2-}, \mathrm{NO}_{3}^{-}, \mathrm{Cl}^{-}, \mathrm{NH}_{4}^{+}$, $\mathrm{K}^{+}, \mathrm{Ca}^{2+}, \mathrm{Mg}^{2+}$ and $\mathrm{Na}^{+}$) using a Metrohm-761 ion chromatograph (IC). Anions were measured with a Shodex SI$904 \mathrm{E}$ column with an eluent of $1.8 \mathrm{mM} \mathrm{Na}_{2} \mathrm{CO}_{3}+1.7 \mathrm{mM}$ $\mathrm{NaHCO}_{3}$. Cations were isolated on a Shodex YK-421
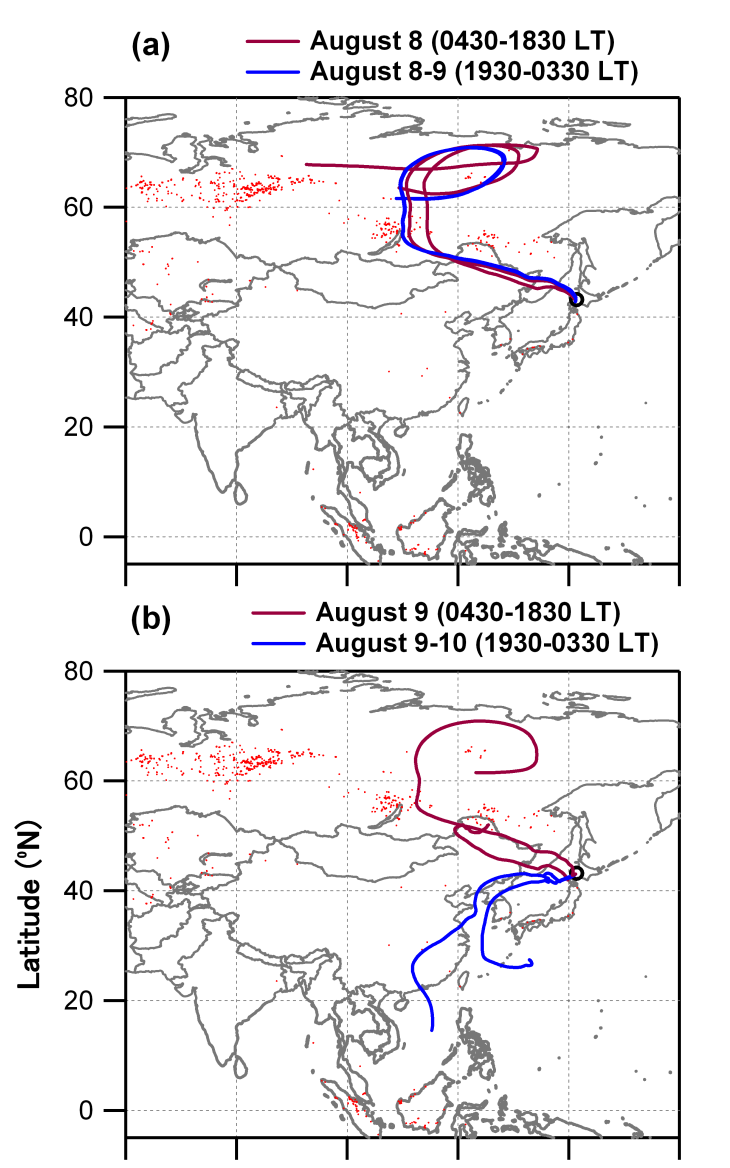

(c) - August 10 (0430-1830 LT)

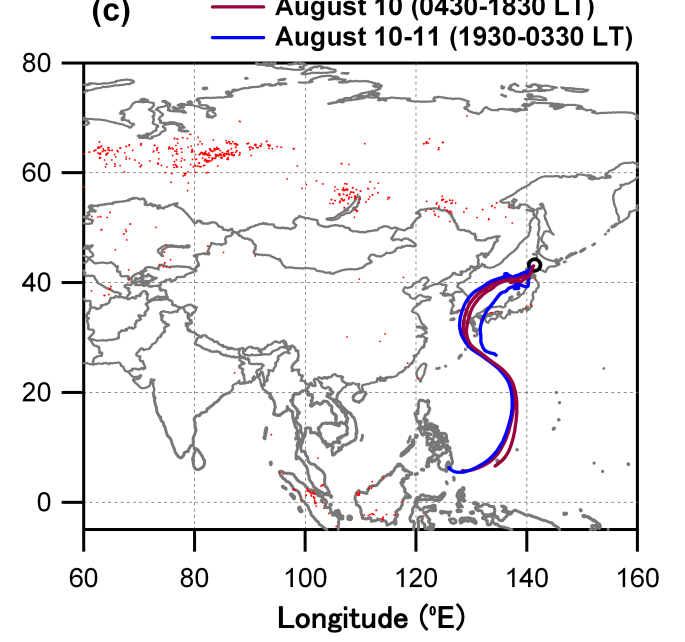

Fig. 1. 10-day air mass backward trajectory analysis results (see Table 1 for the details on air mass types, source regions and their passages for each samples collected during the campaign from 811 August 2005 in Sapporo, northern Japan) overlaid the fire spots searched by the satellite over Siberia and Asia, which were obtained from the European Space Agency website (http://dup.esrin.esa.int/ ionia/about_ionia.asp), from 29 July to 10 August. 


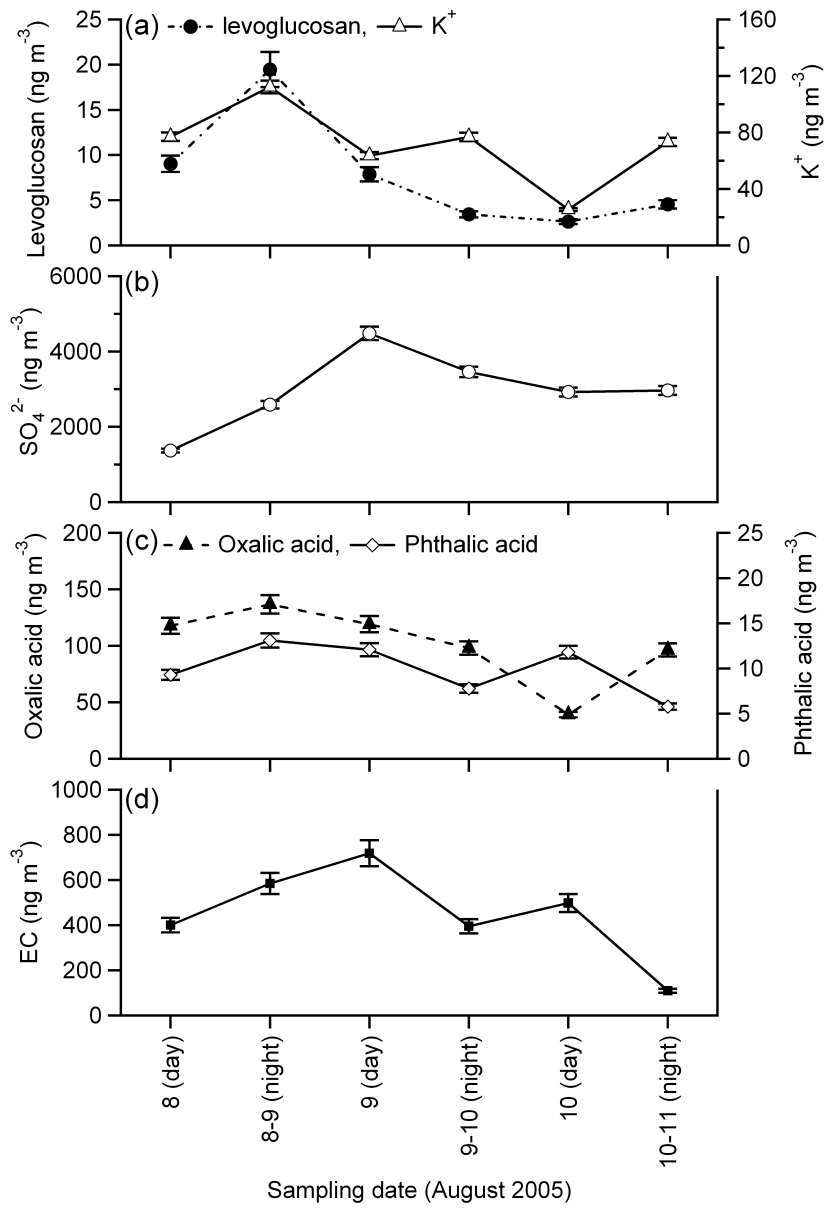

Fig. 2. Concentrations of some marker species determined in fine particles $\left(\mathrm{PM}_{1.1}\right)$ during the campaign from 8-11 August 2005 (error bar shows analytical error calculated as discussed in the text).

column with an eluent of $4 \mathrm{mM} \mathrm{H}_{3} \mathrm{PO}_{4}$. The anionic-IC was equipped with a suppressor, and a $4 \mathrm{mM} \mathrm{H}_{2} \mathrm{SO}_{4}$ solution was used to regenerate suppressor. The analytical errors (repeatability) were estimated to be $4 \%$ based on the duplicate analysis.

Organic and elemental carbon (OC and EC) were determined using a Sunset Lab carbon analyzer, following the Interagency Monitoring of Protected Visual Environments (IMPROVE) thermal evolution protocol and assuming carbonate carbon in the sample to be negligible. Typically, a $1.5 \mathrm{~cm}^{2}$ punch of the filter was placed in a quartz tube inside the thermal desorption chamber of the analyzer, and then stepwise heating was applied (Wang et al., 2005). The analytical errors (reproducibility) were estimated to be within $8 \%$ by the analyses of different punch cuts $(n=3)$ of the same filter samples.

Concentrations of individual compounds, WSOC, OC, EC and inorganic ions reported here are all corrected for the field blanks.

\subsection{Air mass backward trajectories and fire spots}

To characterize the air masses encountered at Sapporo during the campaign, the backward trajectory analysis was performed for each sample using the HYSPLIT4 model (http://www.arl.noaa.gov/ready/hysplit4.html, NOAA Air Resources Laboratory, Silver Spring, Maryland, United States). As lifetime of atmospheric aerosols is believed to be from a week to 10 days (Lim et al., 2003), 10-day backward trajectories were calculated. These trajectories were calculated for air masses starting from the sampling site (with sampling ending time) at $500 \mathrm{~m}$ height using the model vertical velocity and reanalysis data. The flow pattern was updated every $6 \mathrm{~h}$.

Fire spots of biomass burning events from space were searched on the European Space Agency website (http://dup. esrin.esa.int/ionia/wfa). The satellite image shows dense hot spots in Siberia and South Asia from 29 July to 10 August 2005.

\section{Results and discussion}

\subsection{Characteristics of Sapporo aerosols, air mass types and origins}

Chemical compositions of the Sapporo aerosols are largely influenced by continental outflows with lesser contributions of local emissions (Aggarwal and Kawamura, 2009). Figure 1 shows typical air mass trajectories obtained during the sampling period together with fire spots searched by satellite. The trajectories showed that air masses arriving at Sapporo originated from Siberia (8-9 August), China (9-10 August) and the East China Sea/Sea of Japan (10-11 August), whereas fire spots were mostly observed in Siberian and South Asian regions.

To better identify the potential sources of aerosols originating from these regions, we used chemical tracers determined in $\mathrm{PM}_{1.1}$ filter samples collected during the campaign (Fig. 2). For example, levoglucosan and $\mathrm{K}^{+}$are known as potential markers for biomass burning aerosols (Simoneit et al., 1999) whereas $\mathrm{SO}_{4}^{2-}$ is a marker for anthropogenic sources, and/or is an oxidation product of marine-derived dimethylsulfide (DMS) (De Bruyn et al., 1998). Similarly, major diacids are believed to form largely by photooxidation of organic precursors emitted from anthropogenic and biomass burning sources (Kawamura and Ikushima, 1993; Kawamura and Yasui, 2005; Narukawa et al., 1999). EC is primarily emitted from combustion activities (Clarke et al., 2004). In our samples, levoglucosan, $\mathrm{K}^{+}, \mathrm{SO}_{4}^{2-}$, oxalic acid, phthalic acid and EC ranged from 2.6-20, 25-112, 1370-4480, 39$137,5.8-13$ and $110-719 \mathrm{ng} \mathrm{m}^{-3}$, respectively. These tracers were used to strengthen the implications of air mass backward trajectory analyses. 
Table 1. Description of air mass types, source regions, and their passages for the Sapporo aerosol samples collected in summer 2005.

\begin{tabular}{llll}
\hline Sample ID & Sampling date & Air mass types $^{\text {a }}$ & Origin and passage \\
\hline$\# 1$ & 8 August and & Biomass burning & Siberia (lake Baikal and Asian loess regions) \\
$\# 2$ & 8-9 August & Pollution + biomass burning & Siberia, north-east China (Asian loess regions) \\
$\# 3$ & 9 August & Pollution & Eastern China, East China Sea \\
$\# 4$ & 9-10 August & Marine & $\begin{array}{l}\text { East China Sea, Sea of Japan } \\
\text { Marine + mixed sources (i.e., pollution and } \\
\text { biomass burning) }\end{array}$ \\
10 August & 10-11 August & $\begin{array}{l}\text { South Asia, southern Japan, East China Sea, } \\
\text { Sea of Japan }\end{array}$ \\
\hline
\end{tabular}

a This segregation is based on backward trajectory and chemical tracer analyses as discussed in Sect. 3.1. However it does not mean that these are the specific biomass burning, pollution and marine or mixed aerosol samples from a particular origin and region. Local combustionderived emission aerosols are likely also mixed in as a moderate local influence is observed in the samples of 10 August (see Sects. 3.1 and 3.5).

Aerosol samples collected on 8 and 8-9 August are characterized by high concentrations of levoglucosan and $\mathrm{K}^{+}$ (Fig. 2), suggesting an influence of biomass burning. This is consistent with air mass trajectories calculated for these samples (Fig. 1), demonstrating that the air masses were delivered from Siberia, where hot spots of forest fires were observed. Thus these aerosol samples can be considered as biomass burning-influenced samples. In 9 August sample, highest concentrations of $\mathrm{SO}_{4}^{2-}$ (a potential anthropogenic source tracer) and EC (a tracer of combustion) were obtained. The air masses for this sample travelled over Siberia and loess regions in East Asia, hence this sample can be regarded as pollution + biomass burning-influenced sample. Oxalic acid also showed higher concentrations in these samples $(8$, 8-9 and 9 August), further supporting that these samples are potentially influenced by biomass burning or pollution + biomass burning emissions. Similarly, relatively abundant $\mathrm{SO}_{4}^{2-}$ was detected in the 9-10 August sample (for which the source region was eastern China). This sample can be considered as pollution-influenced sample. Although $\mathrm{K}^{+}$is relatively abundant in this sample, concentration of levoglucosan is very low, suggesting no significant contribution from biomass burning.

Moderate concentrations of $\mathrm{SO}_{4}^{2-}$ were found in 10 and 10-11 August samples (Fig. 2), suggesting an influence of marine and local anthropogenic origin. Interestingly, backward trajectory analyses show that air masses for these samples travelled across the East China Sea and Sea of Japan (Fig. 1). The air mass of 10-11 August sample was delivered through South Asia and southern Japan. The $10 \mathrm{Au}-$ gust sample showed a peak of phthalic acid (formed by photooxidation of aromatics emitted from fuel combustion) and EC, indicating a possible influence of local emissions. On the other hand, phthalic acid and EC became lowest in the 10-11 August sample, although $\mathrm{K}^{+}$, levoglucosan and oxalic acid are abundant. Therefore, this sample can be regarded as marine- + pollution- + biomass burning- (i.e., mixed sources) influenced sample. According to the information, each sam- ple can be labelled to represent the influence of particular or mixed sources as summarized in Table 1.

It is important to note that the segregation of the samples based on backward trajectory and chemical tracer analyses does not mean that these are the specific biomass burning, pollution and marine or mixed aerosol samples from a particular origin and region. It is likely that local combustion emission aerosols also mixed in, as the local influence is fairly observed in the samples of 10 August. This is a limitation of this approach using the trajectories and chemical tracers.

\subsection{Size distributions of dicarboxylic acids and related compounds}

Characterizations of aerosol water-soluble organic carbon (WSOC) at molecular level are important to better understand their ability to act as $\mathrm{CCN}$ and estimate the hygroscopic growth factor of organics (McFiggans et al., 2005; Shilling et al., 2007). Dicarboxylic acids (diacids) are known as major water-soluble compound classes that affect the hygroscopic property of aerosols (McFiggans et al., 2005). Diacids are largely formed via photochemical processes. Their contributions to total aerosol carbon increase from the western Pacific rim to the central Pacific (Aggarwal and Kawamura, 2008; Kawamura and Sakaguchi, 1999). Therefore, their size-segregated compositions are useful to better understand the atmospheric processing of aerosols during transport (Mochida et al., 2007).

Saturated straight chain $\left(\mathrm{C}_{2}-\mathrm{C}_{12}\right)$, branched chain and unsaturated dicarboxylic acids, midchain keto or hydroxy dicarboxylic acids $\left(\mathrm{kC}_{3}, \mathrm{kC}_{7}, \mathrm{hC}_{4}\right)$, ketoacids $\left(\omega \mathrm{C}_{2}-\omega \mathrm{C}_{9}\right.$, Pyr) and $\alpha$-dicarbonyls $\left(\mathrm{C}_{2}-\mathrm{C}_{3}\right)$ were determined in each stage of size-segregated aerosols. Their concentrations in fine, i.e., $\mathrm{PM}_{1.1}(<1.1 \mu \mathrm{m})$ and coarse $(>1.1 \mu \mathrm{m})$ particles are summarized in Table 2 . Total concentrations of diacids ranged from $113-274 \mathrm{ng} \mathrm{m}^{-3}$ (mean: $201 \pm 56 \mathrm{ng} \mathrm{m}^{-3}$ ) and 24-71 $\mathrm{ng} \mathrm{m}^{-3}\left(45 \pm 12 \mathrm{ng} \mathrm{m}^{-3}\right)$ in fine and coarse modes, respectively. Oxalic acid $\left(\mathrm{C}_{2}\right)$ was found as the most abundant 
Table 2. Concentrations $\left(\mathrm{ng} \mathrm{m}^{-3}\right)$ of dicarboxylic acids, ketoacids and dicarbonyls in the size-segregated aerosols from Sapporo, northern Japan.

\begin{tabular}{|c|c|c|c|c|}
\hline \multirow[t]{2}{*}{ Compounds } & \multicolumn{2}{|c|}{ Fine mode $\left(D_{p}<1.1 \mu \mathrm{m}\right)$} & \multicolumn{2}{|c|}{ Coarse mode $\left(D_{p}>1.1 \mu \mathrm{m}\right)$} \\
\hline & Range & Mean \pm SD & Range & Mean \pm SD \\
\hline \multicolumn{5}{|c|}{ Dicarboxylic acids } \\
\hline \multicolumn{5}{|c|}{ Saturated straight chain diacids } \\
\hline Oxalic, $\mathrm{C}_{2}$ & 39-137 & $101 \pm 34$ & $7.2-32$ & $17 \pm 7.0$ \\
\hline Malonic, $\mathrm{C}_{3}$ & $20-48$ & $35 \pm 9.1$ & $3.2-13$ & $8.1 \pm 2.5$ \\
\hline Succinic, $\mathrm{C}_{4}$ & $20-33$ & $25 \pm 4.6$ & $5.1-12$ & $7.7 \pm 1.7$ \\
\hline Glutaric, $\mathrm{C}_{5}$ & $0.76-6.8$ & $4.2 \pm 2.6$ & $0.27-2.8$ & $1.7 \pm 0.70$ \\
\hline Adipic, $\mathrm{C}_{6}$ & $1.8-4.7$ & $3.4 \pm 1.3$ & $0.57-1.4$ & $0.93 \pm 0.24$ \\
\hline Pimelic, $\mathrm{C}_{7}$ & $0.12-0.38$ & $0.22 \pm 0.10$ & $0.06-0.35$ & $0.15 \pm 0.08$ \\
\hline Suberic, $\mathrm{C}_{8}$ & BDL & BDL & BDL-0.55 & $0.23 \pm 0.15$ \\
\hline Azelaic, $\mathrm{C}_{9}$ & $1.2-2.7$ & $1.8 \pm 0.61$ & $0.33-2.0$ & $0.81 \pm 0.35$ \\
\hline Sebacic, $\mathrm{C}_{10}$ & $0.53-2.3$ & $1.3 \pm 0.64$ & $0.04-0.33$ & $0.14 \pm 0.07$ \\
\hline Undecanedioic, $\mathrm{C}_{11}$ & BDL-2.1 & $1.1 \pm 0.94$ & BDL-0.40 & $0.12 \pm 0.12$ \\
\hline Dodecanedioic, $\mathrm{C}_{12}$ & BDL-0.11 & $0.03 \pm 0.05$ & $\mathrm{BDL} \pm 0.03$ & $0.01 \pm 0.01$ \\
\hline \multicolumn{5}{|l|}{ Unsaturated diacids } \\
\hline Maleic, M & $1.4-3.4$ & $2.3 \pm 0.91$ & $0.49-1.3$ & $0.80 \pm 0.17$ \\
\hline Fumeric, F & $0.31-1.6$ & $0.87 \pm 0.51$ & $0.18-0.65$ & $0.33 \pm 0.14$ \\
\hline Methylmaleic, mM & $1.1-2.7$ & $1.6 \pm 0.60$ & $0.27-1.2$ & $0.60 \pm 0.21$ \\
\hline Phthalic, $\mathrm{Ph}$ & $5.8-13$ & $10 \pm 2.8$ & $0.81-7.3$ & $2.8 \pm 1.4$ \\
\hline Iso-phthalic, iPh & $0.10-1.5$ & $0.50 \pm 0.48$ & $0.04-0.39$ & $0.14-0.08$ \\
\hline Tere-phthalic, $\mathrm{tPh}$ & BDL-3.1 & $1.3 \pm 1.5$ & BDL-0.59 & $0.25-0.18$ \\
\hline \multicolumn{5}{|l|}{ Branched chain diacids } \\
\hline Methylmalonic, $\mathrm{iC}_{4}$ & $0.57-1.2$ & $0.77 \pm 0.29$ & $0.11-0.82$ & $0.48-0.18$ \\
\hline Methylsuccinic, $\mathrm{iC}_{5}$ & $0.49-1.4$ & $0.92 \pm 0.33$ & $0.15-0.75$ & $0.38 \pm 0.16$ \\
\hline Methylglutaric, $\mathrm{iC}_{6}$ & $1.4-3.4$ & $2.3-0.91$ & $0.49-1.3$ & $0.80 \pm 0.17$ \\
\hline \multicolumn{5}{|c|}{ Keto or hydroxy diacids } \\
\hline Malic, $\mathrm{hC}_{4}$ & BDL-0.26 & $0.09 \pm 0.13$ & $0.04-0.37$ & $0.16 \pm 0.10$ \\
\hline Oxomalonic, $\mathrm{kC}_{3}$ & $1.2-6.6$ & $3.5 \pm 2.2$ & $0.25-1.9$ & $0.72 \pm 0.40$ \\
\hline 4-Oxopimelic, $\mathrm{kC}_{7}$ & $1.2-8.2$ & $5.1 \pm 2.8$ & $0.16-1.4$ & $0.56 \pm 0.40$ \\
\hline Total diacids & $113-274$ & $201 \pm 56$ & $24-71$ & $45 \pm 12$ \\
\hline \multicolumn{5}{|l|}{ Ketoacids } \\
\hline Pyruvic, Pyr & $2.4-8.0$ & $4.8 \pm 2.2$ & $0.46-1.6$ & $1.1 \pm 0.33$ \\
\hline Glyoxylic, $\omega \mathrm{C}_{2}$ & $7.7-15$ & $12 \pm 3.4$ & $1.0-3.6$ & $1.9 \pm 0.69$ \\
\hline 3-Oxopropanoic, $\omega \mathrm{C}_{3}$ & BDL-0.21 & $0.07 \pm 0.09$ & BDL-0.27 & $0.15 \pm 0.08$ \\
\hline 4-Oxobutanoic, $\omega \mathrm{C}_{4}$ & $0.32-9.9$ & $4.6 \pm 3.9$ & $0.71-10$ & $4.2 \pm 2.3$ \\
\hline 9-Oxononanoic, $\omega \mathrm{C}_{9}$ & BDL-4.2 & $1.3 \pm 1.6$ & BDL-0.73 & $0.14 \pm 0.19$ \\
\hline Total ketoacids & $17-27$ & $23 \pm 3.4$ & $3.9-14$ & $7.5 \pm 2.3$ \\
\hline \multicolumn{5}{|l|}{$\alpha$-Dicarbonyls } \\
\hline Glyoxal, Gly & $0.85-3.2$ & $1.8 \pm 0.77$ & BDL-0.71 & $0.40 \pm 0.17$ \\
\hline Methylglyoxal, meGly & $0.26-4.8$ & $2.9 \pm 1.7$ & $0.25-1.7$ & $0.91 \pm 0.40$ \\
\hline Total dicarbonyls & $2.1-8.0$ & $4.8 \pm 2.2$ & $0.50-2.4$ & $1.3 \pm 0.50$ \\
\hline
\end{tabular}

$\mathrm{BDL}=$ below detection limit $\left(\right.$ ca. $\left.0.005 \mathrm{ng} \mathrm{m}^{-3}\right)$

species with concentration range of $39-137 \mathrm{ng} \mathrm{m}^{-3}$ in fine mode (mean: $101 \pm 34 \mathrm{ng} \mathrm{m}^{-3}$ ) and $7.2-32 \mathrm{ng} \mathrm{m}^{-3}$ in coarse mode (mean: $17 \pm 7.0 \mathrm{ng} \mathrm{m}^{-3}$ ), followed by malonic $\left(\mathrm{C}_{3}\right)$ or succinic acid $\left(\mathrm{C}_{4}\right)$. Relative abundances of $\mathrm{C}_{2}, \mathrm{C}_{3}$ and $\mathrm{C}_{4}$ in total diacids were $49 \pm 7.5,18 \pm 0.9$ and $13 \pm 2.4 \%$ in fine mode, and $38 \pm 6.5,18 \pm 2.6$ and $18 \pm 3.1 \%$ in coarse mode. Longer-chain diacids such as $\mathrm{C}_{8}, \mathrm{C}_{11}$ and $\mathrm{C}_{12}$ were below the detection limit (ca. $0.005 \mathrm{ng} \mathrm{m}^{-3}$ ) in some segregated aerosol fractions, probably due to the limited air volume for multiple stages. 


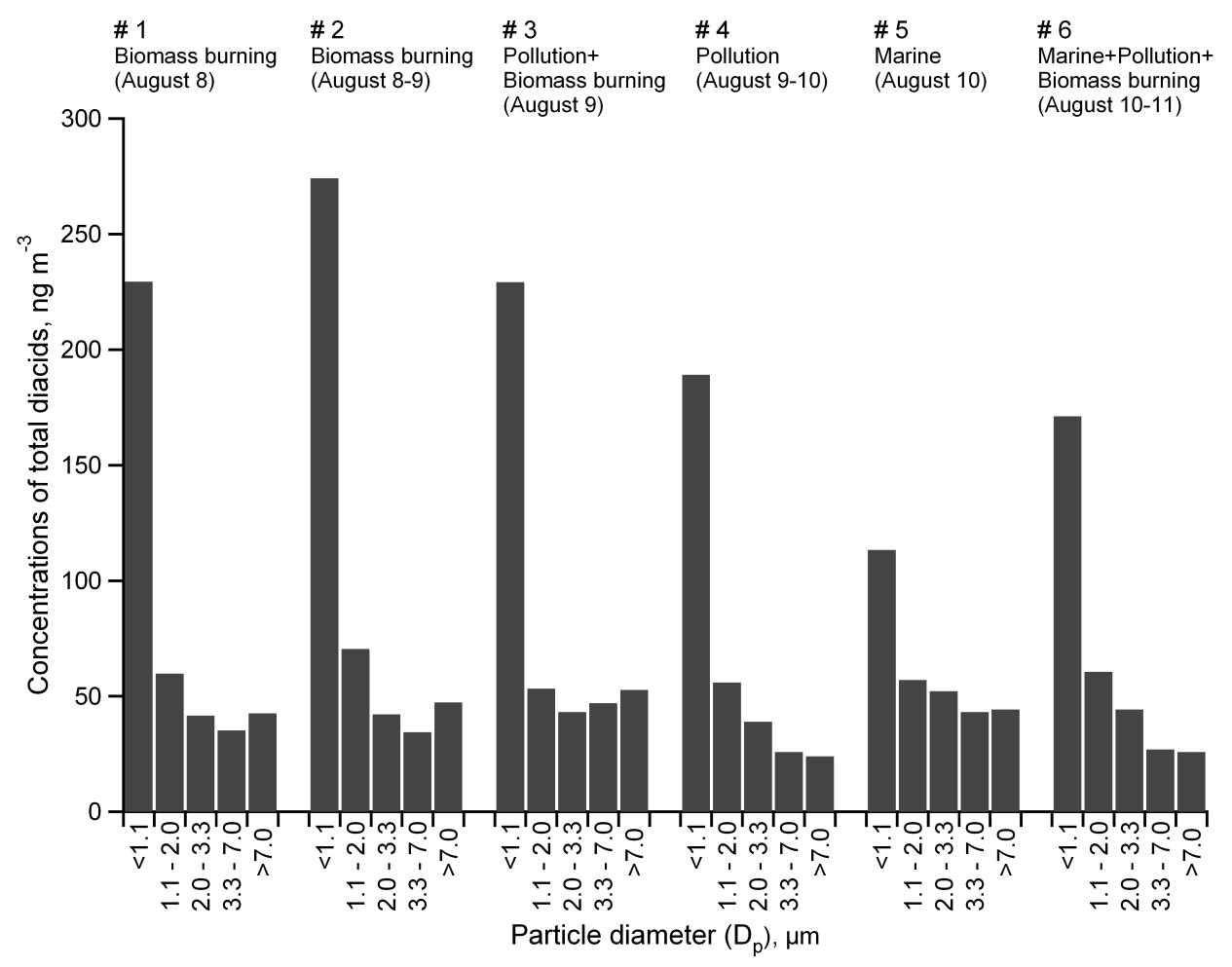

Fig. 3. Size distributions of total diacids in the Sapporo aerosols collected in summer 2005.

It is important to note that diacid concentrations may considerably vary depending on extraction and derivatization methods employed (Yang and Yu, 2008). For example, oxalic acid concentrations determined by organic solvent extraction followed by BSTFA derivatization and GC/MS measurement were found to be significantly lower (about 15 times) than those of oxalate determined by water extraction followed by IC measurement in $\mathrm{PM}_{2.5}$ collected in Singapore (Yang and Yu, 2008). Further, oxalic and malonic acids were not detected and/or seriously depleted when organic solvent extraction/methyl ester derivatization techniques were employed for GC determination (Grosjean et al., 1979; Satsumabayashi et al., 1989). However, our method (water extraction followed by dibutyl ester derivatization and GC determination) proved that the recovery of oxalic acid is $80 \%$ as mentioned before. Kawamura and Barrie found a good correlation $(r=0.84)$ between the oxalic acid concentrations determined in the Arctic aerosols by IC and GC methods (unpublished results, 2002).

Size distributions of total diacids are shown in Fig. 3. The results demonstrate that concentrations of total diacids are maximized in fine particles $\left(\mathrm{PM}_{1.1}\right)$. Similar submicron maxima have been reported in the polluted urban air in Hungary (Kriváscy and Molnár, 1998) and in rural and urban sites in Hongkong (Yao et al., 2002). Other studies also showed the predominance of shorter-chain diacids in fine particles (Kawamura et al., 2007; Mochida et al., 2007; Narukawa et al., 2003).
It is important to state that the chemical composition associated with fine $(<1 \mu \mathrm{m})$ and coarse $(>1 \mu \mathrm{m})$ particles is important to better understand the atmospheric processing of the particles, while the size resolved chemical composition, especially for below $0.5 \mu \mathrm{m}$ sizes is very useful for constraining the $\mathrm{CCN}$ activity of the particles and the properties of the formed clouds. Therefore, we briefly discuss here the size resolved chemical composition obtained from MOUDI (Micro Orifice Uniform Deposit Impactor) sampler (MSP Corp.). During the campaign, we collected one set of MOUDI samples in parallel with the Andersen impactor sampling from 8-11 August using aluminium substrate for 10 stages, and a backup quartz filter (all were pre-combusted at $450{ }^{\circ} \mathrm{C}$ for at least $12 \mathrm{~h}$ ). Size cut-point diameters were 18, 10, 5.6, 3.2, $1.8,1.0,0.56,0.32,0.18,0.10,0.056 \mu \mathrm{m}$ with a flow rate of $30 \mathrm{l} / \mathrm{min}$.

A detailed discussion on these MOUDI samples will be given elsewhere (Aggarwal et al., 2010), however, we present the mass and total diacids concentrations in Fig. 4, which were determined using gravimetric and GC methods, respectively. Aerosol mass and total diacid concentrations show almost similar pattern of distribution, with a peak at the particle size bin of $0.56-1.0 \mu \mathrm{m}$. However, substantial concentrations of total diacids are observed in $0.32-0.56$ and below $0.32 \mu \mathrm{m}$ size ranges, which are important for $\mathrm{CCN}$ activity of aerosol particles. Aerosol mass concentrations obtained in the particle size $<0.56 \mu \mathrm{m}$ is almost equivalent to that determined in particle size bin $0.56-1.0 \mu \mathrm{m}$. In contrast, concentrations of 


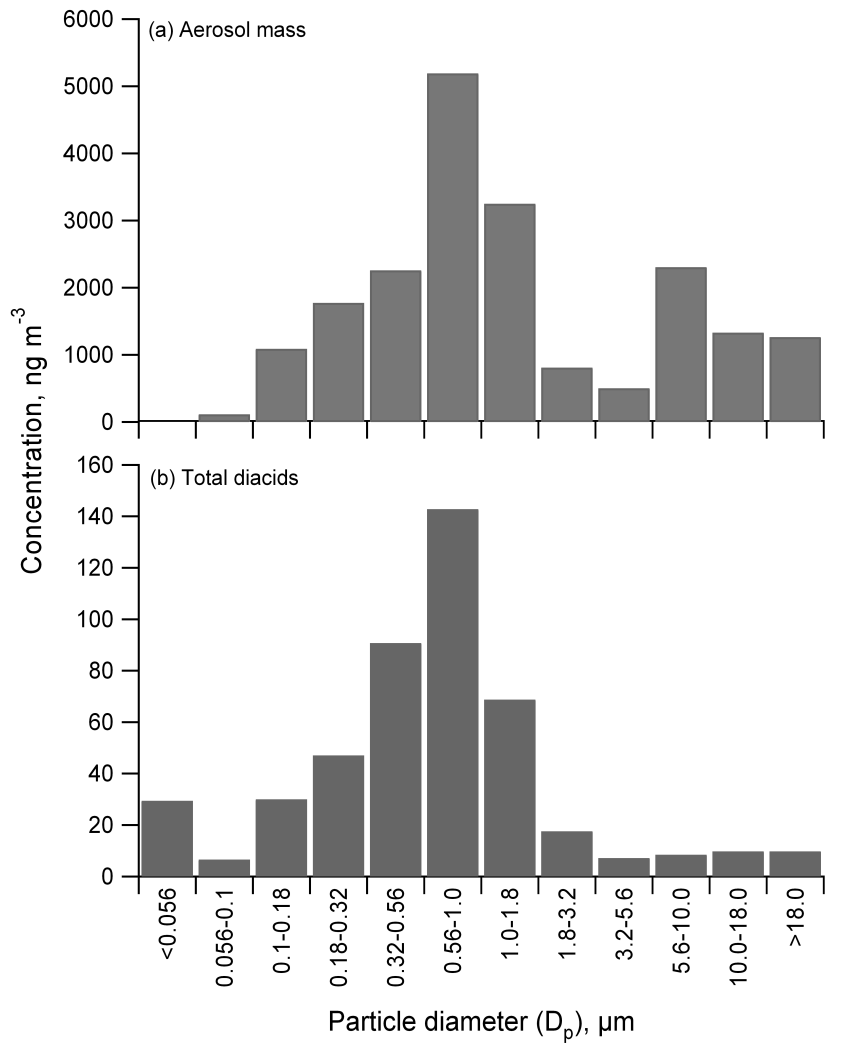

Fig. 4. One set of MOUDI samples was collected during the study period from 8-11 August. (a) aerosol mass collected on aluminium substrate of 10 stages, (b) total diacids concentration distribution (10 stages + backup).

total diacids in the particle size $<0.56 \mu \mathrm{m}$ are much higher than that of $0.56-1.0 \mu \mathrm{m}$ size bin (Fig. 4). These findings are also consistent with the hypothesis that low molecular weight diacids are the secondary oxidation products via gasto-particle conversion in the atmosphere. This point is further discussed in Sect. 3.6.

The biomass burning (samples \#1 and \#2) or biomass burning + pollution (\#3) aerosols showed higher concentrations of total diacids in $\mathrm{PM}_{1.1}$ than those of pollution (\#4), marine (\#5) or marine + mixed sourced (\#6) aerosols (Fig. 3). We found a strong correlation between oxalic acid and levoglucosan (a biomass burning tracer, the concentrations are given in Sect. 3.3) $(r=0.94)$, and between total diacids and levoglucosan $(r=0.86)$ in fine particles $\left(\mathrm{PM}_{1.1}\right)$. In contrast, both oxalic acid and total diacids showed no correlation against fine particle sulfate ( $r=0.07$ and 0.11 , respectively). This suggests that biomass burning is a potential source of diacids and their precursors. These results indicate that biomass burning episodes have a significant influence on the aerosol compositions in northern Japan during the campaign. During biomass burning events, firstly, diacids can be produced by thermal oxidation of biomass and be subsequently condensed onto pre-existing particles in the biomass burning plumes (Gao et al., 2003; Narukawa et al., 1999; Reid et al., 1998). Secondly, production of diacids via photochemical aging of intermediate smoke species (gas-to-particle conversion) in the atmosphere is another important pathway (Gao et al., 2003; Narukawa et al., 1999). Thirdly, production of diacids through aqueous phase reactions in aerosols may also be an important pathway (Sorooshian et al., 2006; Warneck, 2003).

Figure 5 shows individual concentrations of major diacid and ketoacid species detected in the size-segregated aerosol samples. Although diacids and ketoacids are generally more abundant in the fine size $(<1.1 \mu \mathrm{m})$ than coarse sizes $(>1.1 \mu \mathrm{m})$, they also exist with considerable amounts in the coarse mode $\left(D_{p}>1.1 \mu \mathrm{m}\right)$. In particular, azelaic acid $\left(\mathrm{C}_{9}\right)$ is abundantly present in coarse mode such as $3.3-7.0 \mu \mathrm{m}$ or $>7.0 \mu \mathrm{m}$ in diameter, i.e., $\mathrm{C}_{9}$ is more abundant in coarse particles $(>1.1 \mu \mathrm{m})$ in all the sample sets (Table 2, Fig. 5d). The relatively high abundance of $\mathrm{C}_{9}$ in coarse particles can be interpreted by heterogeneous oxidation of $\Delta 9$ double bond of unsaturated fatty acids such as oleic acid $\left(\mathrm{C}_{18: 1}\right)$ and linoleic acid $\left(\mathrm{C}_{18: 2}\right)$, which are derived from phytoplankton, higher plants and bacteria (Kawamura and Gagosian, 1987).

The loadings of diacids in coarse mode $\left(D_{p}>1.1 \mu \mathrm{m}\right)$ are slightly higher than those in fine mode $\left(D_{p}<1.1 \mu \mathrm{m}\right)$ in \#5 and \#6 samples, when the air mass types were categorized as marine or marine + mixed source (see Fig. 5). This suggests a possible association of diacids with sea-salt particles. Generally a shift of size maxima towards course mode is reported when aerosol particles have a marine influence (Huang et al., 2006; Neusüss et al., 2000). During the passage of air masses in the marine boundary layer, a change in the net concentrations of diacids in fine particles may in part occur due to their evaporation and subsequent deposition on the coarse particles that contain alkaline components. Mochida et al. (2003) also reported a shift of small diacids from submicrometer to supermicrometer sizes in coastal marine aerosols collected from the western North Pacific. Likewise Kerminen et al. (1999) found a concentration peak of diacids in supermicrometer size range in the lower Arctic aerosols. Ricard et al. (2002) reported that $\mathrm{C}_{4}$ and $\mathrm{C}_{5}$ diacids were abundant in coarse particles in the northern Finland aerosols when the air mass type was marine.

Concentrations of total ketoacids in the Sapporo aerosols ranged from $17-27 \mathrm{ng} \mathrm{m}^{-3}$ (mean: $23 \pm 3.4 \mathrm{ng} \mathrm{m}^{-3}$ ) and 3.9$14 \mathrm{ng} \mathrm{m}^{-3}\left(7.5 \pm 2.3 \mathrm{ng} \mathrm{m}^{-3}\right)$ in fine and coarse modes, respectively (Table 2). Glyoxylic acid $\left(\omega \mathrm{C}_{2}\right)$ was found as the dominant ketoacid followed by 4-oxobutanoic acid $\left(\omega \mathrm{C}_{4}\right)$ and/or pyruvic acid (Pyr). Total concentrations of $\alpha$-dicarbonyls ranged from $2.1-8.0 \mathrm{ng} \mathrm{m}^{-3}$ (mean: $\left.4.8 \pm 2.2 \mathrm{ng} \mathrm{m}^{-3}\right)$ and $0.50-2.4 \mathrm{ng} \mathrm{m}^{-3}\left(1.3 \pm 0.50 \mathrm{ng} \mathrm{m}^{-3}\right)$ in fine and coarse modes, respectively. Being similar to diacids, concentrations of ketoacids and dicarbonyls also maximized in fine mode (Table 2). It is of interest to note that these concentrations in fine particles were much more abundant in biomass burning-influenced samples (\#1, \#2 and \#3), as seen 

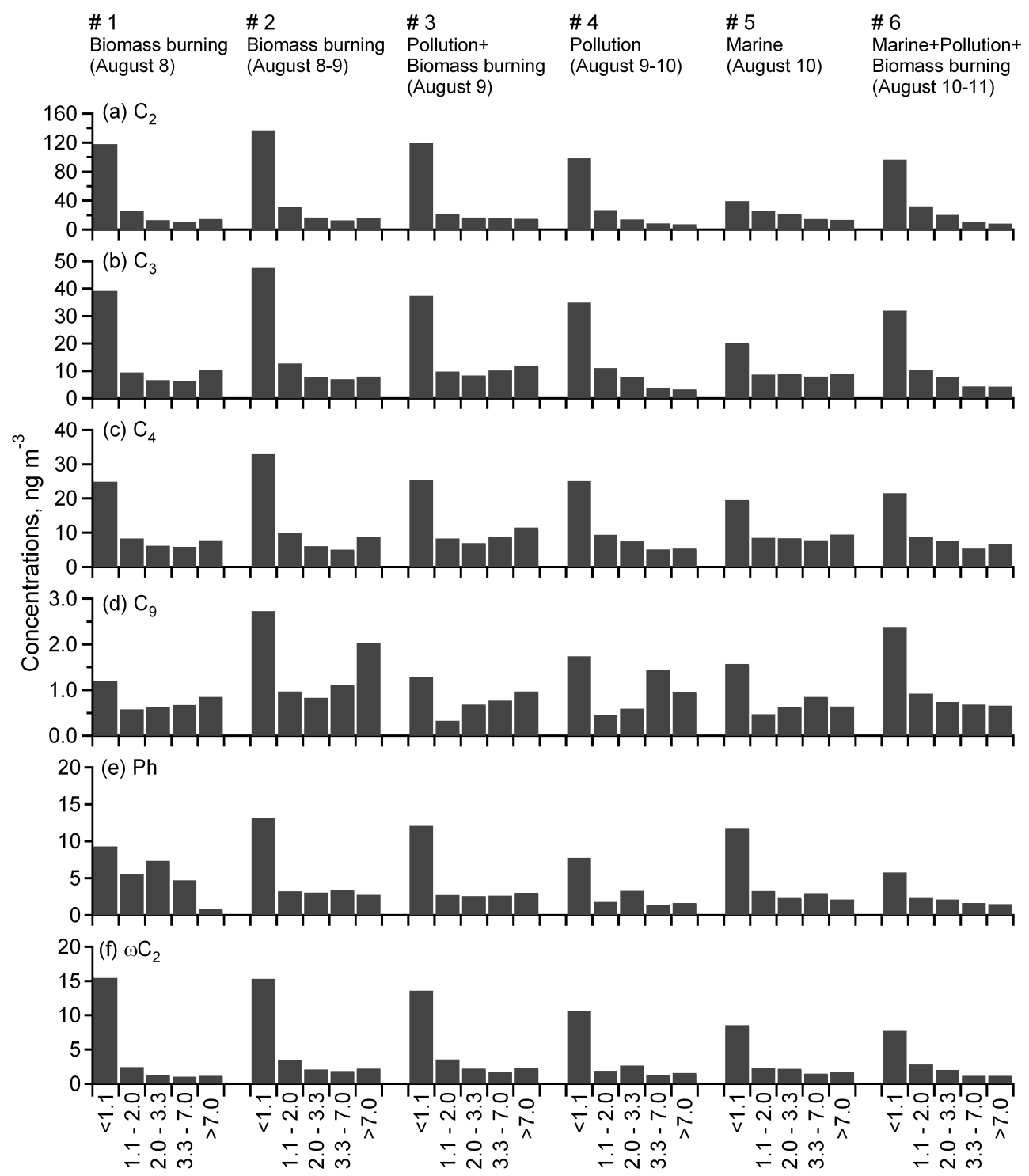

Particle diameter $\left(D_{p}\right), \mu m$

Fig. 5. Size distributions of major diacids and ketoacid in the Sapporo aerosols collected in summer 2005.

in Fig. 5. The correlation coefficients $(r)$ of $\mathrm{C}_{2}$ with $\omega \mathrm{C}_{2}$, Pyr and glyoxal (Gly) are 0.96, 0.90 and 0.87 , respectively (obtained from all respective size-segregated aerosol concentrations). Considering the chemical equilibrium conditions, these strong correlations indicate that these species are important intermediates in the secondary formation pathways of oxalic acid ( $\mathrm{Gly} / \mathrm{Pyr} \rightarrow \omega \mathrm{C}_{2} \rightarrow \mathrm{C}_{2}$ ) from the biogenic precursors (Aggarwal and Kawamura, 2008; Kawamura et al., 1996).

\subsection{Size distributions of sugar compounds}

Because sugars are water-soluble, they can influence the hygroscopic properties of aerosol particles (Mochida and Kawamura, 2004). Eight sugars (i.e., levoglucosan, fruc- tose, glucose, sucrose, trehalose, mannitol, arabitol and inositol) were detected in the Sapporo aerosols. Their concentrations are given in Table 3. Total concentrations of sugars ranged from $5.6-31 \mathrm{ng} \mathrm{m}^{-3}$ (mean: $14 \pm 9.2 \mathrm{ng} \mathrm{m}^{-3}$ ) in fine $(<1.1 \mu \mathrm{m})$ particles and $1.9-74 \mathrm{ng} \mathrm{m}^{-3}\left(19 \pm 18 \mathrm{ng} \mathrm{m}^{-3}\right)$ in coarse $(>1.1 \mu \mathrm{m})$ particles. Levoglucosan is the most abundant sugar detected in fine size $\left(\mathrm{PM}_{1.1}\right)$ (Table 3). However, other sugar compounds become dominant in coarse modes of most samples. Among them (in coarse mode), glucose and sucrose are most abundant on average (Table 3). Levoglucosan comprised $54 \pm 9.3 \%$ of total sugars in fine mode, but did only $2.5 \pm 0.95 \%$ in coarse mode. Instead, glucose and sucrose accounted for $23 \pm 1.9 \%$ and $20 \pm 7.8 \%$ of total sugars in coarse mode, respectively. 
Table 3. Concentrations $\left(\mathrm{ng} \mathrm{m}^{-3}\right.$ ) of sugar compounds in the size-segregated aerosols from Sapporo, northern Japan.

\begin{tabular}{lcccc}
\hline Compounds & \multicolumn{2}{c}{ Fine mode $\left(D_{p}<1.1\right)$} & \multicolumn{2}{c}{ Coarse mode $\left(D_{p}>1.1\right)$} \\
& Range & Mean \pm SD & Range & Mean \pm SD \\
\hline Levoglucosan & $2.6-20$ & $7.8 \pm 6.2$ & $0.09-1.8$ & $0.50 \pm 0.40$ \\
Fructose & $1.1-4.1$ & $2.1 \pm 1.2$ & $0.19-5.7$ & $1.3 \pm 1.6$ \\
Glucose & $0.50-3.4$ & $1.7 \pm 1.1$ & $0.29-14$ & $4.2 \pm 3.9$ \\
Sucrose & $0.10-1.5$ & $0.69 \pm 0.49$ & $0.07-26$ & $3.9 \pm 7.1$ \\
Trehalose & $0.10-0.55$ & $0.28 \pm 0.19$ & $0.21-19$ & $3.3 \pm 4.8$ \\
Mannitol & $0.10-1.4$ & $0.69 \pm 0.50$ & $0.17-11$ & $3.3 \pm 2.9$ \\
Arabitol & $0.10-0.89$ & $0.35 \pm 0.29$ & $0.12-6.1$ & $2.0 \pm 1.7$ \\
Inositol & $0.10-0.49$ & $0.29 \pm 0.14$ & $0.02-0.40$ & $0.10 \pm 0.10$ \\
Total sugars & $5.6-31$ & $14 \pm 9.2$ & $1.9-74$ & $19 \pm 18$ \\
\hline
\end{tabular}

Levoglucosan (1,6-anhydro- $\beta$-D-glucopyranose), anhydrosaccharide, is a major pyrolysis product of cellulose, and is recognised as a tracer of biomass burning (Simoneit et al., 1999). However, it can also be generated by non-combustive processes, e.g., hydrolysis or microbial degradation of carbohydrates (Simoneit et al., 1999, 2000). Although it is believed that levoglucosan is a non-degradable species in the atmosphere, it is important to note that recent studies show that levoglucosan is not as stable as originally thought (Hoffman et al., 2010).

Despite its usefulness in the source apportionment studies, very few studies reported the particle size distributions of levoglucosan (Fine et al., 2004; Herckes et al., 2006; Kleeman et al., 2008; Schkolnik et al., 2005). Figure 6 shows the size distributions of levoglucosan and total sugars during the campaign. Levoglucosan is enriched in fine particles with concentrations of $2.6-20 \mathrm{ng} \mathrm{m}^{-3}$ (mean: $7.8 \pm 6.2 \mathrm{ng} \mathrm{m}^{-3}$ ), especially in biomass burning-influenced samples (\#1 to \#3), although its concentrations in coarse mode are very low (0.09$1.8 \mathrm{ng} \mathrm{m}^{-3}, 0.50 \pm 0.40 \mathrm{ng} \mathrm{m}^{-3}$ ). These results are similar to the size distributions of levoglucosan reported in smoke impacted aerosol samples (Herckes et al., 2006; Schkolnik et al., 2005). This study indicates that biomass burning smoke is spread out over the Asian outflow region, and has an impact on the air quality of the western North Pacific rim (Simoneit et al., 2004b).

On the other hand, other sugar species, i.e., primary saccharides including monosaccharides (glucose and fructose), disaccharides (inositol, sucrose and trehalose) and sugar polyols or reduced sugars (arabitol and mannitol) are found to exist mostly in coarse fractions. The size distributions of individual primary saccharides are shown in Fig. 7. They show maximum concentrations in coarse sizes $(>1.1 \mu \mathrm{m})$. The primary saccharides are derived from fungal spores (Lewis and Smith, 1967; Bieleski, 1982) and plant materials (Bartolozzi et al., 1997; Baker et al., 1998; Pacini, 2000) (which are airborne or become airborne due to biomass burning), and by resuspension of surface soil and unpaved road dust (Simoneit et al., 2004c). Recently, Russell et al. (2010) reported the prevalence of sugar compounds in ocean aerosols via bubble bursting processes.

Fructose shows bimodal distributions peaking at $\mathrm{PM}_{1.1}$ and in coarse sizes (Fig. 7a, Table 3). Interestingly, its concentrations in $\mathrm{PM}_{1.1}$ were found to be high in \#1, \#2, \#3 and \#6 samples (biomass burning and mixed aerosols), and to well correlate with levoglucosan in $\mathrm{PM}_{1.1}(r=0.83)$. This relation likely suggests that fructose is in part emitted from biomass burning processes. Low to moderate concentrations of glucose were also found in fine particles in biomass burning-influenced samples, i.e., \#1, \#2 and \#3 (Fig. 7b). Fu et al. (2008) and references therein suggested that biomass burning is the primary source of glucose, fructose, galactosan and mannosan along with levoglucosan. Medeiros et al. (2006) also observed that wildfires strongly enhanced the emissions of uncombusted saccharides. Interestingly, inositol also shows bimodal distributions (Fig. 7c), being similar to fructose distributions. This again suggests its biomass burning sources.

In contrast, arabitol and mannitol (reduced sugars) did not show any significant enrichment in fine particles (Fig. 7d and e). Their concentrations maximized in coarse sizes in all the sample sets (unimodal distributions), with higher concentrations in \#1, \#2 and \#3 samples. Similarly, sucrose was found to be abundant in coarse particles $(>7.0 \mu \mathrm{m})$ (Fig. 7f), and its maximum concentrations were found in \#2 and \#3 samples (moderately correlated $(r=0.60)$ to $\mathrm{Ca}^{2+}$ at coarse size $>7.0 \mu \mathrm{m})$. Another disaccharide, trehalose is also enriched in coarse sizes $(3.3-7.0 \mu \mathrm{m},>7.0 \mu \mathrm{m})$ with maximum concentration on 8-9 August (Fig. 7g). The disaccharides detected in coarse particles may be derived from the suspended soil dusts originated in Sapporo and/or Asian continent, where agriculture-tilling practices are the source for the emission of soil dusts into the passing aerosols (Simoneit et al., 2004b).

The elevated concentrations of sugar polyols (arabitol and mannitol) and trehalose in coarse mode may be attributed to biological sources like fungal spores (Yttri et al., 2007). 


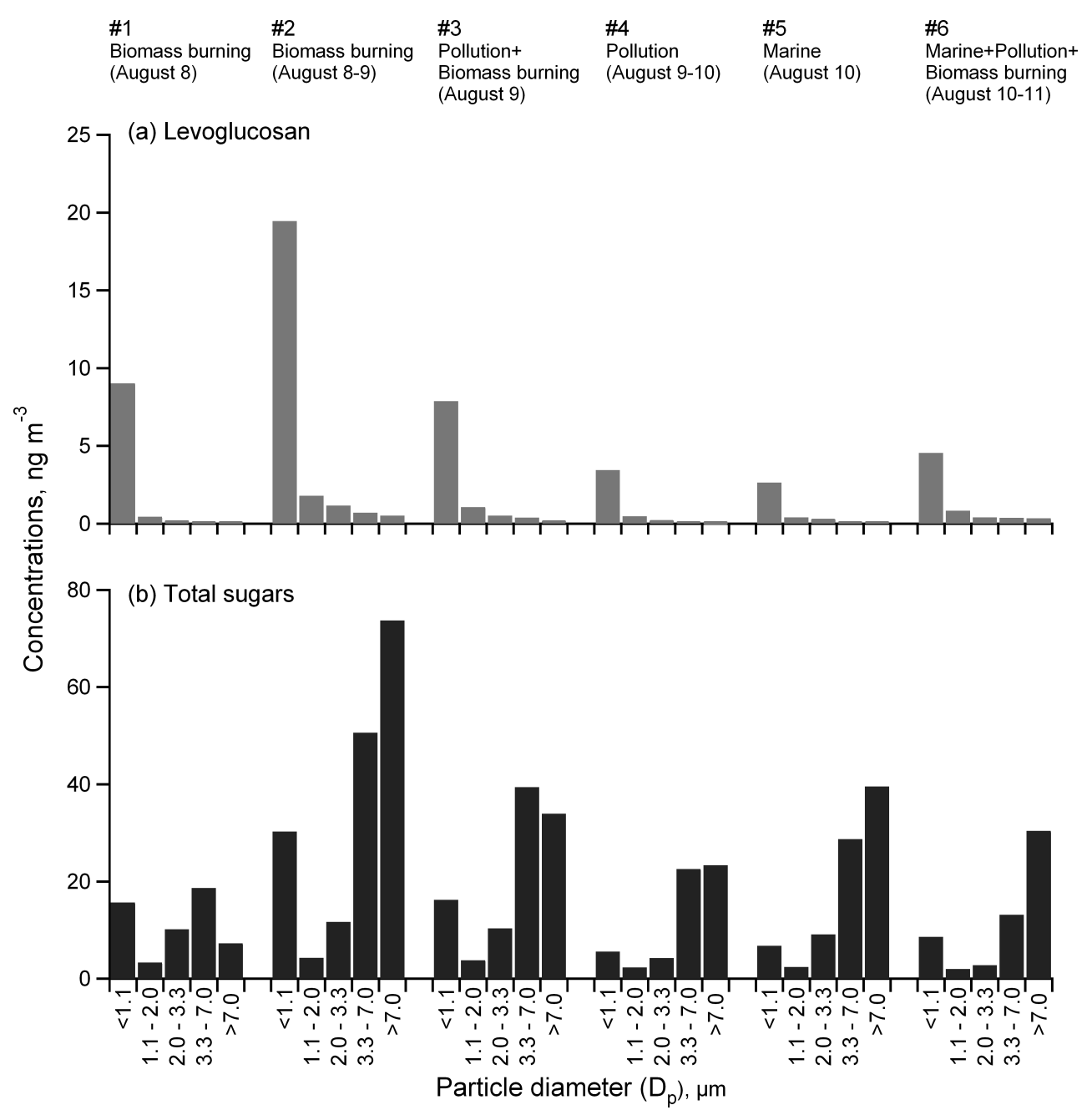

Fig. 6. Size distributions of (a) levoglucosan and (b) total sugars in the Sapporo aerosols collected in summer 2005.

During late summer, spores from fungi are most intensively emitted. Bauer et al. (2002) reported the diameters of smallest fungal spores of $2 \mu \mathrm{m}$, underlining their presence in the coarse sizes (i.e., 2.0-3.3, 3.3-7.0, >7.0 $\mu \mathrm{m}$ ). They are also major soluble components in the bark of trees, branches and leaves (Medeiros et al., 2006). Coarse mode sucrose could also be associated with phloem of plants and developing leaves and flower buds (Bieleski, 1995) in addition to suspended soil dust and unpaved road dust. Further, small fractions of disaccharides and reduced sugars in fine mode detected in this study may be attributed to biomass burning ( $\mathrm{Fu}$ et al., 2008, and references therein) or sources like pollens and some viruses (Yttri et al., 2007, and reference therein).

\subsection{Size distributions of inorganic ions}

Size distributions of inorganic ions (i.e., $\mathrm{SO}_{4}^{2-}, \mathrm{NH}_{4}^{+}$, $\mathrm{K}^{+}, \mathrm{NO}_{3}^{-}, \mathrm{Ca}^{2+}, \mathrm{Cl}^{-}$, and $\mathrm{Mg}^{2+}$ ) determined in the aerosol samples are shown in Fig. 8. Re- sults of $\mathrm{Na}^{+}$(sea-salt) are not given here because of possible artifact from glass containers used in this study. Total concentrations of inorganic ions ranged from 2030-6970 $\mathrm{ng} \mathrm{m}^{-3}$ (mean: $4630 \pm 1620 \mathrm{ng} \mathrm{m}^{-3}$ ) and $322-2590 \mathrm{ng} \mathrm{m}^{-3}\left(1020 \pm 630 \mathrm{ng} \mathrm{m}^{-3}\right)$ in fine and coarse aerosols, respectively. Among identified ions, $\mathrm{SO}_{4}^{2-}$ was found as the most abundant species, ranging from 1370 $4480 \mathrm{ng} \mathrm{m}^{-3}$ (mean: $2970 \pm 1020 \mathrm{ng} \mathrm{m}^{-3}$ ) in fine mode and $126-1610 \mathrm{ng} \mathrm{m}^{-3}\left(518 \pm 446 \mathrm{ng} \mathrm{m}^{-3}\right)$ in coarse mode. The second most abundant ion is $\mathrm{NH}_{4}^{+}$, whose concentrations are $447-2370 \mathrm{ng} \mathrm{m}^{-3}\left(1460 \pm 627 \mathrm{ng} \mathrm{m}^{-3}\right)$ and $65-801 \mathrm{ng} \mathrm{m}^{-3}$ $\left(248 \pm 210 \mathrm{ng} \mathrm{m}^{-3}\right)$ in fine and coarse modes, respectively. It is of interest to note that average molar ratios $\left(\mathrm{NH}_{4}^{+} / \mathrm{SO}_{4}^{2-}\right)$ are $>2$ in both fine and coarse modes, suggesting that sulfate is neutralized by ammonium in the Sapporo aerosols. Ranges and mean concentrations of individual ions are summarized in Table 4.

$\mathrm{SO}_{4}^{2-}$ accounted for $64 \pm 1.6 \%$ and $45 \pm 14 \%$ of total inorganic ion mass in fine and coarse modes, respectively. Higher 


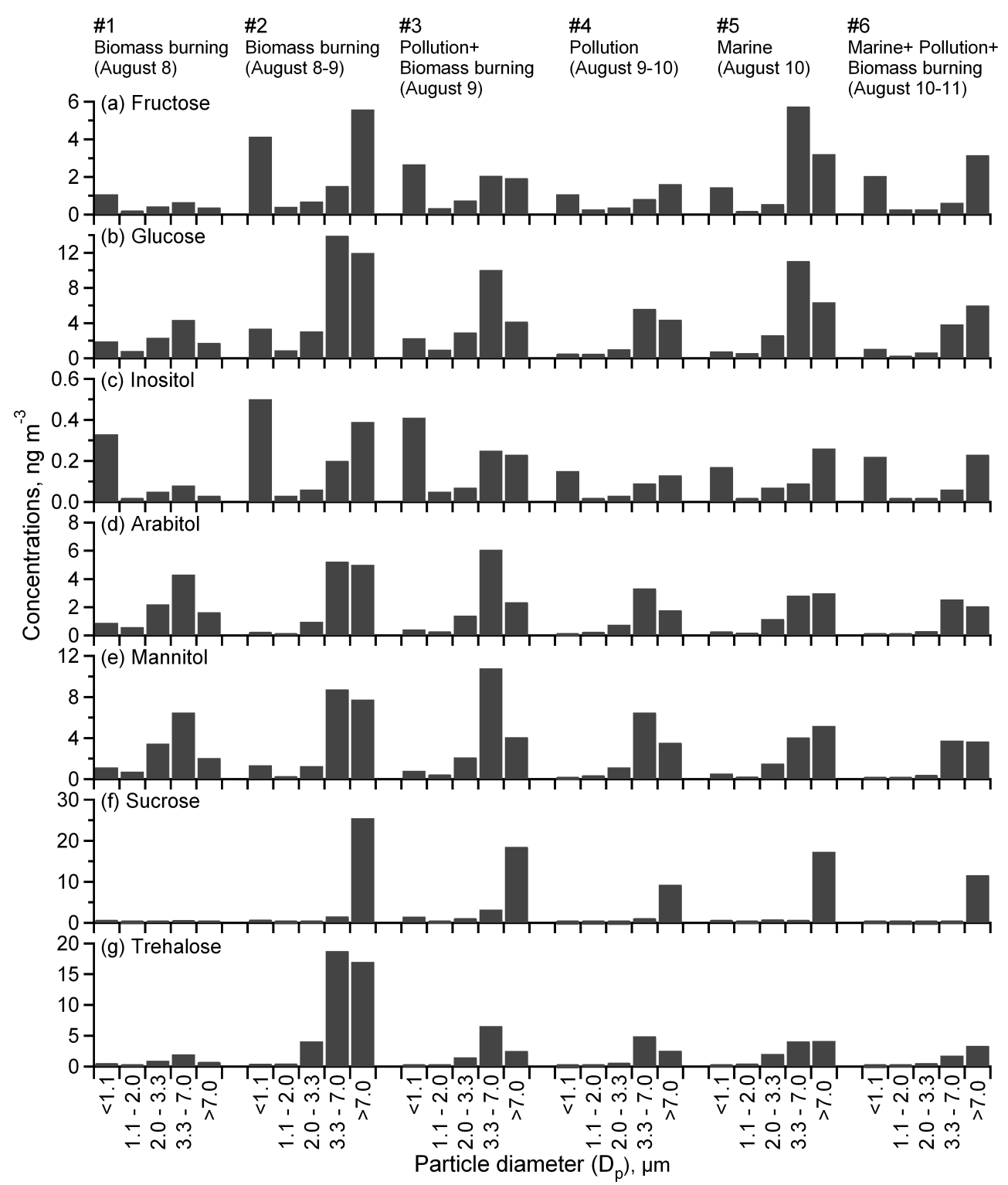

Fig. 7. Size distributions of individual sugar compound classes in the Sapporo aerosols collected in summer 2005.

$\mathrm{SO}_{4}^{2-}$ concentrations were obtained on $9,9-10$ and $10-11$ August (Fig. 8a), when the air masses were transported from Asian continent. Although $\mathrm{SO}_{4}^{2-}$ is enriched in $\mathrm{PM}_{1.1}$, substantial fractions of $\mathrm{SO}_{4}^{2-}$ were also found in the size intervals of $1.1-2.0$ and $2.0-3.3 \mu \mathrm{m}$, possibly due to the coagulation of fine particles enriched with $\mathrm{SO}_{4}^{2-}$ in-cloud processes at different levels of relative humidity (Kerminen and Wexler, 1995; Zhao and Gao, 2008). Negligible fractions of $\mathrm{SO}_{4}^{2-}$ were found in larger coarse sizes (i.e., 3.3-7.0 and >7.0 $\mu \mathrm{m}$ ), indicating that $\mathrm{SO}_{4}^{2-}$ does not associate with dust and sea-salt particles in our samples. Size distributions of $\mathrm{NH}_{4}^{+}$are comparable to those of $\mathrm{SO}_{4}^{2-}$, and do not change significantly depending on the types of air masses (Fig. 8b). The correlation between $\mathrm{NH}_{4}^{+}$and $\mathrm{SO}_{4}^{2-}$ is very strong $(r=0.99)$ in $\mathrm{PM}_{1.1}$ as well as in coarse sizes $(r=0.97,0.99$ and 0.93 for the size bins of 1.1-2.0, 2.0-3.3 and 3.3-7.0 $\mu \mathrm{m}$, respectively), suggesting the presence of ammonium salt of $\mathrm{SO}_{4}^{2-}$. The overall concentrations of $\mathrm{NH}_{4}^{+}$and $\mathrm{SO}_{4}^{2-}$ in biomass burning samples (\#1 and \#2) were lower than those in the pollution-influenced aerosol samples (\#3 and \#4).

$\mathrm{K}^{+}$is a useful tracer of biomass burning. Being consistent with levoglucosan, $\mathrm{K}^{+}$was most abundantly detected in fine particles $\left(\mathrm{PM}_{1.1}\right)$ in all the sample sets (Fig. 8c), again indicating the impact of biomass burning in this region. Considerable amounts of $\mathrm{K}^{+}$were also found in coarse modes of 1.1-2.0 and 2.0-3.3 $\mu \mathrm{m}$. Because potassium salts are more hygroscopic in nature, such a size shift of potassium may be rather effective due to aging process of biomass burning 


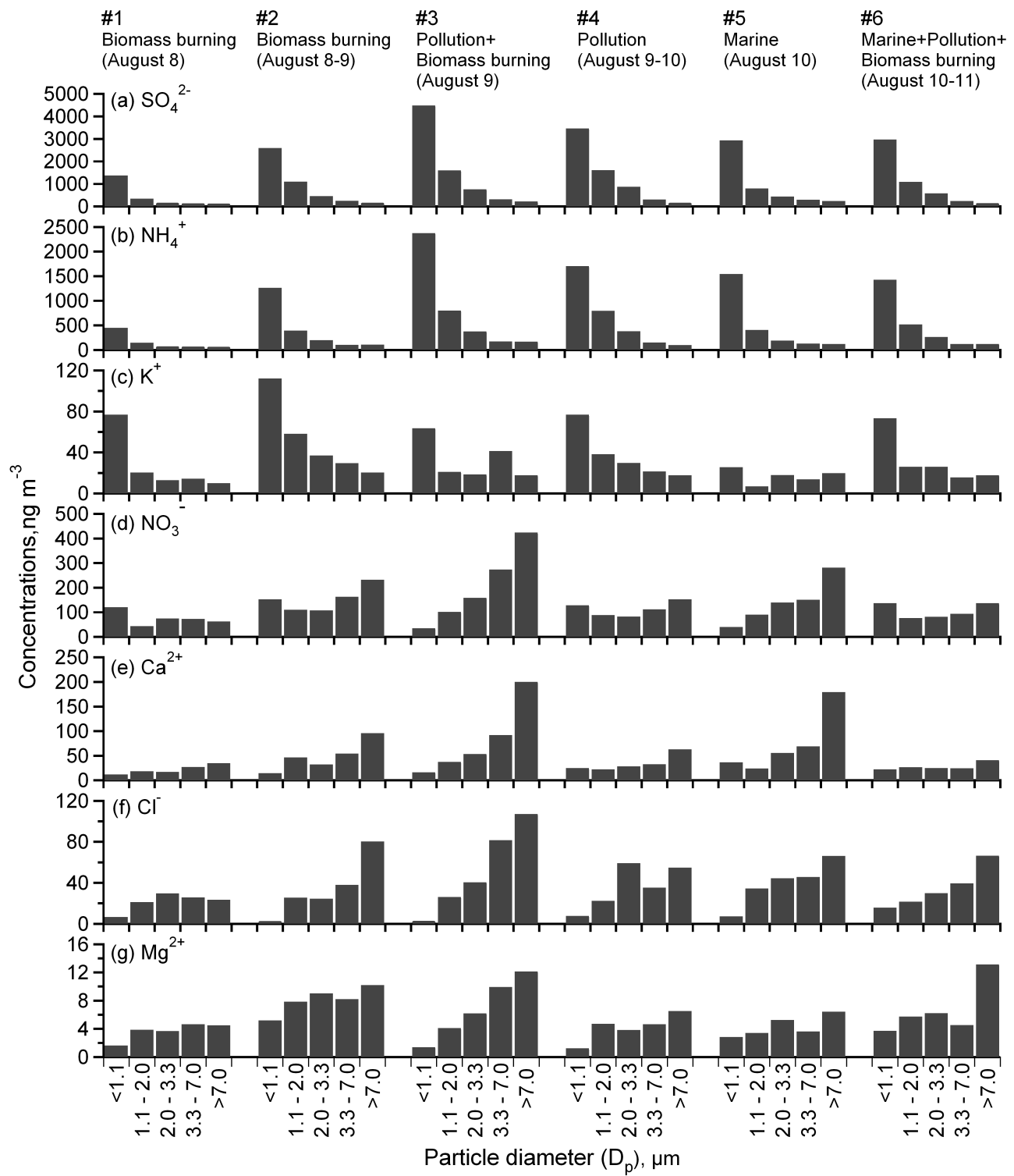

Fig. 8. Size distributions of individual inorganic ions in the Sapporo aerosols collected in summer 2005.

aerosols (Huang et al., 2006). $\mathrm{K}^{+}$detected in coarse modes of 3.3-7.0 and $>7.0 \mu \mathrm{m}$ is possibly derived from soil and seasalt.

Interestingly, size distributions of $\mathrm{NO}_{3}^{-}$showed two peaks at $\mathrm{PM}_{1.1}$ and size bin $>7.0 \mu \mathrm{m}$ in most of the sample sets regardless the air mass types (Fig. 8d). Particulate $\mathrm{NO}_{3}^{-}$in the coarse modes could have been formed from neutralization reactions of $\mathrm{HNO}_{3}$ on sea-salt and soil dust particles (Herner et al., 2006; Zhuang et al., 1999). However, $\mathrm{NO}_{3}^{-}$ concentrations in our samples were rather low (range: $35-$ 152 and $44-424 \mathrm{ng} \mathrm{m}^{-3}$ ), which represented only $2.7 \pm 2.0$ and $17 \pm 10 \%$ of total inorganic ion mass in fine and coarse modes, respectively. Both $\mathrm{NO}_{3}^{-}$and EC (discussed in the following section) are tracers for fossil fuel burning, however low concentrations of $\mathrm{NO}_{3}^{-}$relative to $\mathrm{EC}$ in fine modes (Table 4) are possibly due to the evaporative losses of $\mathrm{NO}_{3}^{-}$during transport. Similar values $\left(15-130 \mathrm{ng} \mathrm{m}^{-3}\right.$ ) of $\mathrm{NO}_{3}^{-}$were reported in the western North Pacific for fine particles collected during spring, however, the concentrations of coarse mode (1700-5000 $\mathrm{ng} \mathrm{m}^{-3}$ ) were more than 10 times higher than those of fine mode (Mochida et al., 2007). Oxidation of $\mathrm{NO}_{\mathrm{x}}$ to $\mathrm{HNO}_{3}$ and the subsequent adsorption on salt/dust particles may be a process responsible for the higher concentrations of $\mathrm{NO}_{3}^{-}$in the coarse mode.

$\mathrm{Ca}^{2+}$ (a potential indicator of mineral dust) were at maximum concentration in coarse size $(>7.0 \mu \mathrm{m})$ (Fig. 8e) Higher concentrations of $\mathrm{Ca}^{2+}$ were observed in \#2, \#3 and \#5 samples. This is consistent with air mass trajectories, 

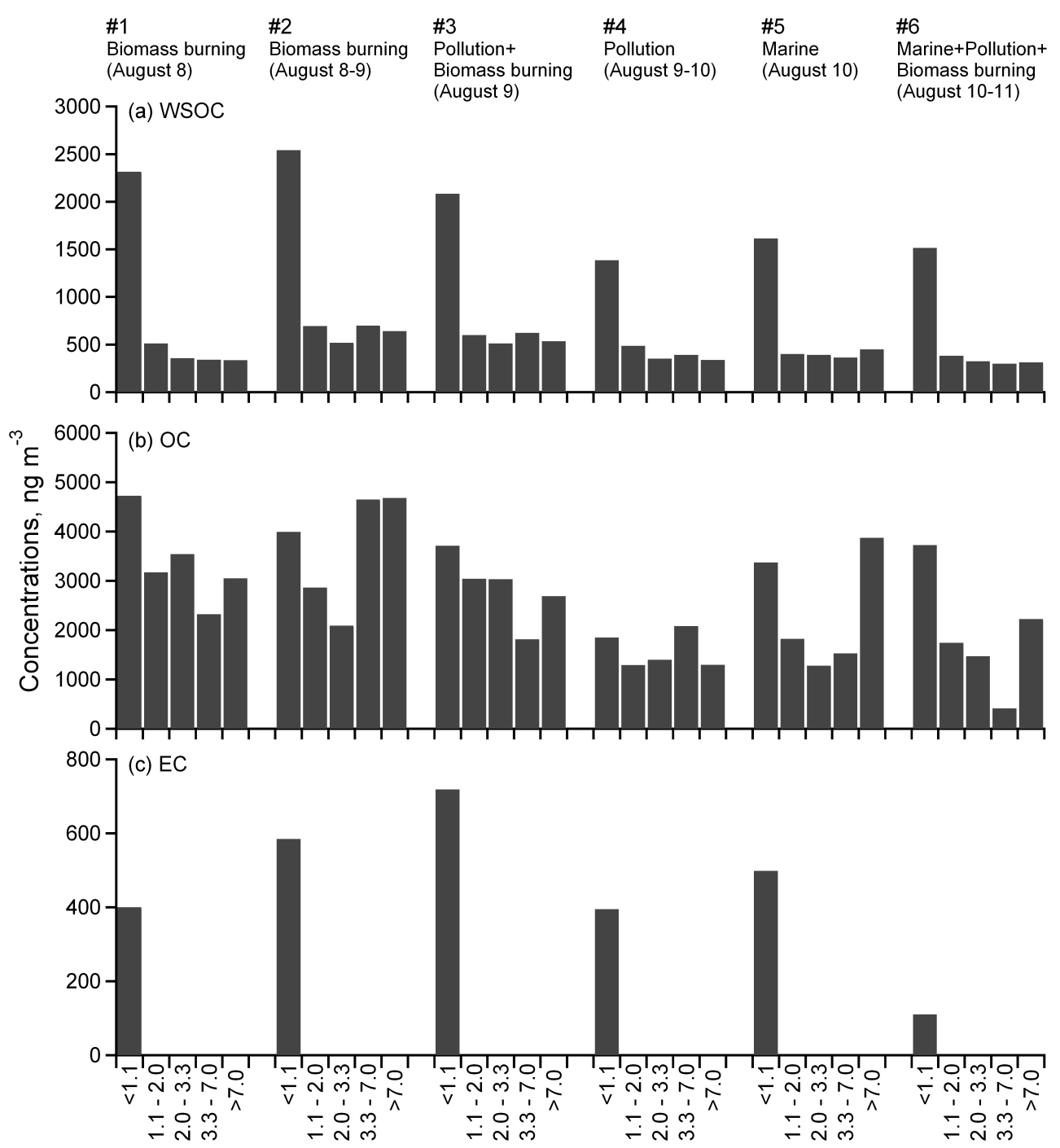

Particle diameter $\left(D_{p}\right), \mu m$

Fig. 9. Size distributions of carbonaceous species in the Sapporo aerosols collected in summer 2005.

Table 4. Concentrations $\left(\mathrm{ng} \mathrm{m}^{-3}\right.$ ) of WSOC, OC, EC and major ions in the size-segregated aerosols from Sapporo, northern Japan.

\begin{tabular}{lcccc}
\hline Major constituents & \multicolumn{2}{c}{ Fine mode $\left(D_{p}<1.1\right)$} & \multicolumn{2}{c}{ Coarse mode $\left(D_{p}>1.1\right)$} \\
& Range & Mean \pm SD & Range & Mean \pm SD \\
\hline WSOC & $1390-2540$ & $1910 \pm 472$ & $297-699$ & $452 \pm 126$ \\
$\mathrm{OC}$ & $1850-4730$ & $3560 \pm 954$ & $412-4680$ & $2390 \pm 1090$ \\
$\mathrm{EC}$ & $110-719$ & $451 \pm 207$ & & \\
$\mathrm{SO}_{4}^{2-}$ & $1370-4480$ & $2970 \pm 1020$ & $126-1610$ & $518 \pm 446$ \\
$\mathrm{NO}_{3}^{-}$ & $35-152$ & $102 \pm 51$ & $44-424$ & $138 \pm 87$ \\
$\mathrm{Cl}^{-}$ & $3-16$ & $7 \pm 5$ & $21-107$ & $43 \pm 23$ \\
$\mathrm{NH}_{4}^{+}$ & $447-2370$ & $1460 \pm 627$ & $65-801$ & $248 \pm 210$ \\
$\mathrm{~K}^{+}$ & $25-112$ & $71 \pm 28$ & $7-58$ & $23 \pm 11$ \\
$\mathrm{Ca}^{2+}$ & $12-37$ & $21 \pm 9$ & $17-200$ & $54 \pm 47$ \\
$\mathrm{Mg}^{2+}$ & $1-5$ & $3 \pm 2$ & $3-13$ & $6 \pm 3$ \\
$\mathrm{Total}^{2+}$ inorganic ions & $2030-6970$ & $4630 \pm 1620$ & $322-2590$ & $1020 \pm 630$ \\
\hline
\end{tabular}


which show their passage over loess regions in China, the source regions of mineral dusts in East Asia. In \#5 sample, the air masses came from the East China Sea, which is a receptor region of the dust/soil particles originated from Mongolia and Eastern China (Mochida et al., 2007; Simoneit et al., 2004b). $\mathrm{Cl}^{-}$concentrations maximized at coarse sizes (Fig. 8f). $\mathrm{Cl}^{-}$concentrations were very low, ranging from 3-16 $\mathrm{ng} \mathrm{m}^{-3}$ and $21-107 \mathrm{ng} \mathrm{m}^{-3}$ in fine and coarse modes, respectively. Being similar to $\mathrm{Cl}^{-}, \mathrm{Mg}^{2+}$ were also at maximum concentrations in coarse sizes (Fig. 8g), suggesting a similar origin and source regions, i.e., sea-salts.

\subsection{Size distributions of WSOC, OC and EC}

Size distributions of water-soluble organic carbon (WSOC), organic carbon (OC) and elemental carbon (EC) are shown in Fig. 9. Their concentrations are summarized in Table 4. EC was only detected in fine mode $\left(D_{p}<1.1 \mu \mathrm{m}\right)$. In all the sample sets, WSOC maximized in fine aerosols (mean: $1910 \pm 472 \mathrm{ng} \mathrm{m}^{-3}$ ) (Fig. 9a). In fine modes, WSOC concentrations of samples \#1, \#2 and \#3 are about 30-60\% higher than those of \#4, \#5 and \#6 samples. This means that WSOC is enriched in biomass burning-influenced aerosols. Because WSOC is an important fraction of OC, high loadings of WSOC in biomass burning-influenced aerosols indicate that Siberian biomass burning events may significantly impact on air quality, physical and optical properties of aerosols, and thus climate of the western North Pacific rim. A considerable amount of WSOC is also observed in marine influenced samples (\#5 and \#6), indicating that ocean bubble bursting may be a potential source of polar organics in marine aerosol (Russell et al., 2010).

Although OC generally peaked in fine particles (Fig. 9b), a peak was also found in coarse particles. This bimodal distribution of OC may be a result of in-cloud processing of organic aerosols during long-range atmospheric transport. Alternatively, OC may be associated with sugar-related sources because this distribution pattern is similar to that of sugar compounds. As discussed above, possible source of sugars is soil resuspension (microorganisms and plant debris) and ocean bubble bursting (especially in marine influenced samples), both of which may also be an important source for OC loadings in coarse aerosols. However, by comparing OC concentrations in all the sample sets in fine or coarse modes or total concentrations (i.e., fine + coarse mode) separately, we found that $\mathrm{OC}$ is always higher in the biomass burning or biomass burning+ pollution aerosol samples. These results suggest that although soil resuspensions, atmospheric processes and ocean bubble bursting are potentially important for OC distributions in coarse mode, biomass burning is the major source that governs the OC loadings in the Sapporo aerosols during the summer campaign.

$\mathrm{EC}$ in $\mathrm{PM}_{1.1}$ ranged from $110-719 \mathrm{ng} \mathrm{m}^{-3}$ with a mean of $451 \pm 207 \mathrm{ng} \mathrm{m}^{-3}$. This range and mean are about half of those (range: $620-1400 \mathrm{ng} \mathrm{m}^{-3}$, mean: $840 \pm 340 \mathrm{ng} \mathrm{m}^{-3}$ ) reported for fine aerosol particles $(<1 \mu \mathrm{m})$ collected in spring during Asian dust season in the western North Pacific (Mochida et al., 2007). EC maximized in \#3 sample (pollution + biomass burning) and minimized in \#6 sample (marine + mixed sourced) (Fig. 9c). High EC concentration was also obtained in \#5 sample when air masses were transported from marine region. Phthalic acid (Ph) (see Fig. 5e) and OC (see Fig. 9b) are both moderately enriched in fine mode of this sample. Because $\mathrm{Ph}$ is directly emitted from automobile exhausts (Kawamura and Kaplan, 1987) and also produced by a secondary photochemical oxidation of aromatic hydrocarbons emitted from fossil fuel combustions (Kawamura and Ikushima, 1993), this sample may be considered as partially influenced by fossil fuel combustion of local origins.

\subsection{Characteristic type of WSOC and OC in fine and coarse fractions}

WSOC to OC ratios can be used to assess the photochemical aging of organics, especially in long-range transported aerosols such as Sapporo aerosols (Aggarwal and Kawamura, 2009). Figure 10a illustrates WSOC/OC ratios in sizesegregated aerosols for all the sample sets. Except for \#6 sample, WSOC/OC ratios peaked in fine particles. The ratios calculated for fine and coarse modes are 0.41-0.75 (mean: $0.55 \pm 0.12)$ and $0.10-0.72(0.23 \pm 0.13)$, respectively. Similar results $(\sim 0.2-0.7)$ have been reported in different aerosol types (Duarte et al., 2007 and references therein). Further, high ratios $(>0.4)$ were reported in aged aerosols, and biomass burning-influenced aerosols (Jaffrezo et al., 2005, and references therein). The oxidation of particulate organic matter during long-range transport should be responsible for high WSOC/OC ratios as suggested in our previous study in Sapporo (Aggarwal and Kawamura, 2009). A significant portion of OC may be oxidised to WSOC during the atmospheric transport to the western North Pacific rim from Asian continent.

Diacids are believed to be produced largely by secondary processes. In fact, the smallest diacid $\left(\mathrm{C}_{2}\right)$ is proposed as end product of oxidative reactions of several longer-chain diacids and other organic precursors in the atmosphere (Aggarwal and Kawamura, 2008; Kawamura et al., 1996). Interestingly, size distributions of $\mathrm{C}_{2}$ and total diacids, which showed a peak in $\mathrm{PM}_{1.1}$, are quite similar to those of WSOC in all the sample sets (see Figs. 3, 5a and 9a). We found good correlations between $\mathrm{C}_{2}$ (or $\mathrm{C}_{2}-\mathrm{C}$, i.e., carbon based concentrations) and WSOC ( $r=0.68(0.68)$ ), and total diacids (or total diacidC) and WSOC $(r=0.81(0.85))$ in $\mathrm{PM}_{1.1}$, suggesting that a major portion of WSOC in fine particles is secondarily produced in both biomass burning and polluted plumes. However, the correlation coefficients are low and even negative in the coarse sizes. Furthermore, although $\mathrm{C}_{2}$, total diacids and WSOC showed similar size distributions, their ratios, i.e., $\mathrm{C}_{2}$-C/WSOC and total diacid-C/WSOC, are generally higher 


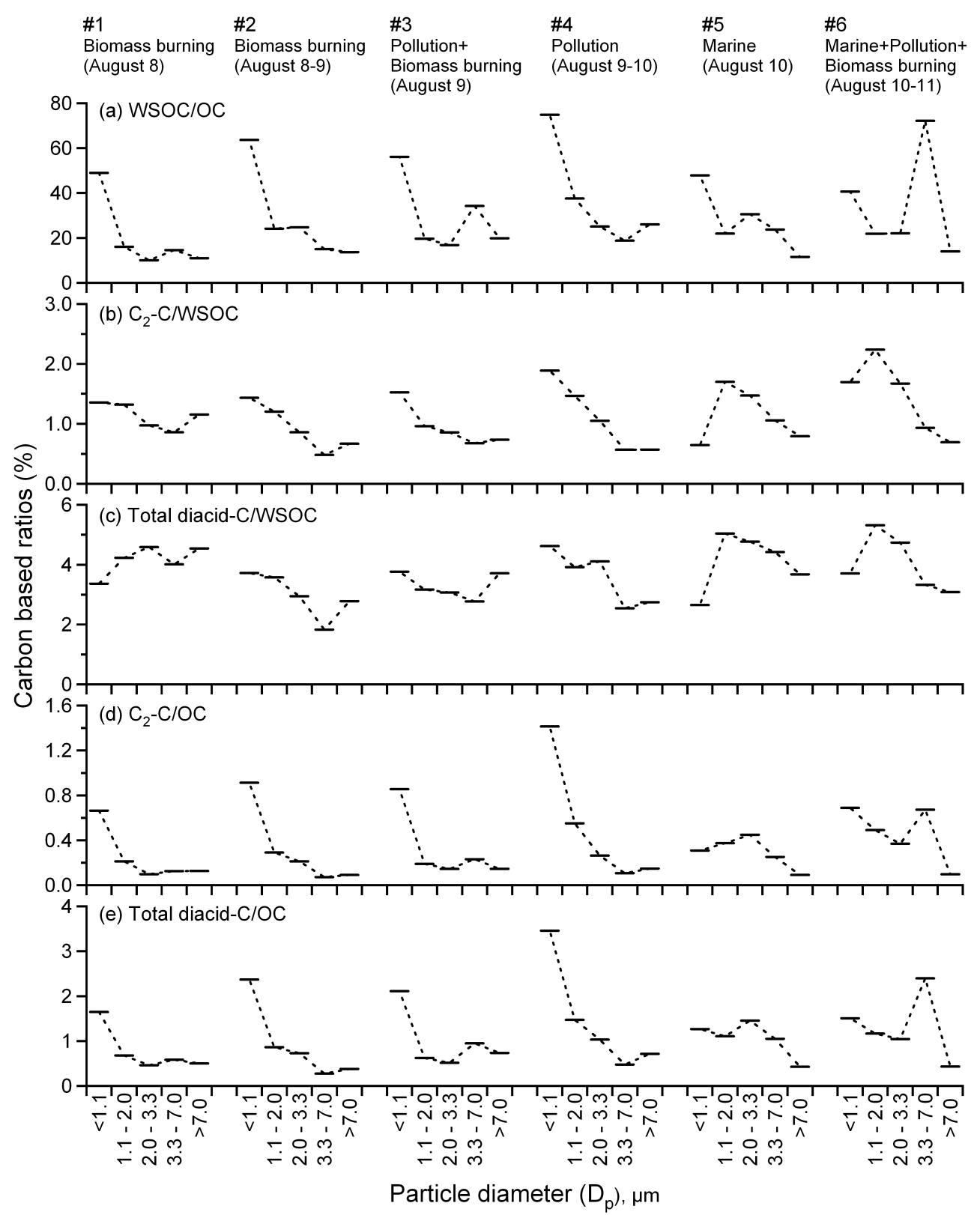

Fig. 10. Size-segregated ratios of (a) WSOC/OC, (b) oxalic acid-C/WSOC, (c) total diacid-C/WSOC, (d) oxalic acid-C/OC and (e) total diacid-C/OC in the aerosol samples collected during the campaign from 8-11 August 2005 in Sapporo, northern Japan.

in $\mathrm{PM}_{1.1}$ than those of coarse sizes in biomass burningor/and pollution-influenced samples (Fig. 10b and c).

In contrast, size distributions of diacids and OC are not parallel in most of the samples (Figs. 3 and $9 \mathrm{~b}$ ). We found enhanced ratios of $\mathrm{C}_{2}-\mathrm{C} / \mathrm{OC}$ and total diacid-C/OC in $\mathrm{PM}_{1.1}$, except for \#5 and \#6 samples (being similar to $\mathrm{C}_{2}$-C/WSOC and total diacid-C/WSOC ratios), where the atmospheric particles were influenced by marine sources (Fig. 10d and e). This can be interpreted by secondary photochemical production of diacids in the atmosphere. In the above two sets of samples, a shift of the mode peak towards larger size ranges was found, again suggesting that oxalic acid and other semivolatile species could have been adsorbed on alkaline seasalt particles. The $\mathrm{C}_{2}-\mathrm{C} / \mathrm{OC}$ and total diacid-C/OC ratios are highest in the aerosol samples influenced by pollution sources (\#4). Because WSOC accounted for more than $50 \%$ of OC in fine aerosols (except marine-influenced aerosols), this study indicates that a considerable fraction of $\mathrm{OC}$ in fine mode is likely formed by the secondary processes that occur in the atmosphere during long-range transport of organic precursors. 


\section{Summary and Conclusions}

Six sets of size-segregated (i.e., with 5 size bins: $<1.1$, $1.1-2.0,2.0-3.3,3.3-7.0,>7.0 \mu \mathrm{m})$ aerosol samples were collected during day-, and night-time in Sapporo, northern Japan in summer 2005. Samples were analyzed for low molecular weight diacids, ketoacids and $\alpha$-dicarbonyls, sugars, WSOC, OC and EC, as well as major ions. Chemical tracer analyses together with air mass backward trajectories demonstrated that during the sampling periods, 3 different air masses encountered at Sapporo with an influence of Siberian biomass burning ( $8,8-9$ August), Chinese pollution (9, 9-10 August) and marine + mixed sources (10, 1011 August). Major water-soluble organic compounds, i.e., diacids, peaked in fine mode $\left(D_{p}<1.1 \mu \mathrm{m}\right)$. By comparing the size distributions, we conclude that diacids are more enriched in biomass burning-influenced samples than pollutionand marine-influenced aerosols. The high loadings of diacids and enhanced ratios of $\mathrm{C}_{2}-\mathrm{C} / \mathrm{OC}$ and diacid-C/OC in fine particles demonstrate that they are most likely produced by photochemical oxidation of organic precursors in the atmosphere during long-range transport. Biomass burning emissions are possibly a major source for diacids and their precursors in the Sapporo aerosols during the campaign.

Levoglucosan showed maximum concentrations in fine mode in all the sample sets. They are several times more abundant in biomass burning-influenced samples. In contrast, other sugars peaked in coarse aerosols $(>1.1 \mu \mathrm{m})$, although most sugars are more enriched in biomass burninginfluenced aerosol samples. $\mathrm{SO}_{4}^{2-}$ (a dominant inorganic ion) showed maximum concentrations in fine mode. We found that it is more abundant in the samples influenced by Chinese aerosols. $\mathrm{Ca}^{2+}$ peaked mostly in coarse mode whereas $\mathrm{NO}_{3}^{-}$showed bimodal distributions with a peak in fine and coarse modes. Higher OC loadings are observed in biomass burning aerosols than pollution aerosols. Similarly, WSOC that peaked in fine mode, showed a maximum concentration in biomass burning aerosols. We observed that WSOC and $\mathrm{OC}$ in fine aerosols are photochemically more processed in the atmosphere than those in coarse mode fractions. This study demonstrates that biomass-burning episodes in Siberia have a significant influence on the carbonaceous aerosols in northern Japan and the western North Pacific rim.

Acknowledgements. This study is in part supported by the Japanese Ministry of Education, Science, Sport and Culture (grant-in-aid Nos. 17340166 and 19204055), and by the Environment Research and Technology Development Fund (B-0903) of the Ministry of the Environment, Japan. Authors are thankful to all anonymous reviewers, and the editor for their valuable comments and suggestions.

Edited by: L. M. Russell

\section{References}

Aggarwal, S. G. and Kawamura, K.: Carbonaceous and inorganic composition in long-range transported aerosols over northern Japan: Implication for aging of water-soluble organic fraction, Atmos. Environ., 43, 2532-2540, 2009.

Aggarwal, S. G. and Kawamura, K.: Molecular distributions and stable carbon isotopic compositions of dicarboxylic acids and related compounds in aerosols from Sapporo, Japan: Implications for photochemical aging during longrange atmospheric transport, J. Geophys. Res., 113, D14301, doi:10.1029/2007JD009365, 2008.

Aggarwal, S. G., Agarwal, S., and Kawamura, K.: Size distribution of diacids in aged aerosols from East Asia suggests their secondary production and degradation, in preparation, 2010.

Baker, H. G., Baker, I., and Hodges, S. A.: Sugar composition of nectars and fruits consumed by birds and bats in the tropics and subtropics, Biotropica, 30, 559-586, 1998.

Bartolozzi, F., Bertazza, G., Bassi, D., and Cristofori, G.: Simultaneous determination of soluble sugars and organic acids as their trimethylsilyl derivatives in apricot fruits by gas-liquid chromatography, J. Chromatogr. A, 758, 99-107, 1997.

Bauer, H., Kasper-Giebl, A., Löflund, M., Geibl, H., Hitzenberger, R., Zibuschka, F., and Puxbaum, H.: The contribution of bacteria and fungal spores to the organic carbon content of cloud water, precipitation and aerosols, Atmos. Res., 64, 109-119, 2002.

Beilesky, R. L.: Onset of phloem export from senescent petals of daylily, Plant Physiol., 109, 557-565, 1995.

Bieleski, R. L.: Sugar alcohols, in: Encyclopedia of Plant Physiology, volume 13A, Plant Carbohydrates, volume I, Intracellular Carbohydrates, edited by: Loewis, A. and Tanner, W., SpringerVerlag, Berlin, 158-170, 1982.

Brock, C. A., Hudson, P. K., Lovejoy, E. R., et al.: Particle characteristics following cloud-modified transport from Asia to North America, J. Geophys. Res., 109, D23S26, doi:10.1029/2003JD004198, 2004.

Claeys, M., Graham, B., Vas, G., Wang, W., Vermeylen, R., Pashynska, V., Cafmeyer, J., Guyon, P., Andreae, M. O., Artaxo, P., and Maenhaut, W.: Formation of secondary organic aerosols through photooxidation of isoprene, Science, 303, 1173-1176, 2004.

Clarke, A. D., Shinozuka, Y., Kapustin, V. N., et al.: Size distributions and mixtures of dust and black carbon aerosol in Asian outflow: Physiochemistry and optical properties, J. Geophys. Res., 109, D15S09, doi:10.1029/2003JD004378, 2004.

De Bruyn, W. J., Bates, T. S., Cainey, J. M., and Saltzman, E. S.: Shipboard measurements of dimethyl sulfide and $\mathrm{SO}_{2}$ southwest of Tasmania during the first Aerosol Characterization Experiment (ACE 1), J. Geophys. Res., 103(D13), 16703-16711, 1998.

Duarte, R. M. B. O., Santos, E. B. H., Pio, C. A., and Duarte, A. C.: Comparison of structural features of water-soluble organic matter from atmospheric aerosols with those of aquatic humic substances, Atmos. Environ., 41, 8100-8113, 2007.

Fine, P. M., Chakrabarti, B., Krudysz, M., Schauer, J. J., and Sioutas, C.: Diurnal variations of individual organic compound constituents of ultra fine and accumulation mode particulate matter in the Los Angeles Basin, Environ. Sci. Technol., 38, 12961304, 2004.

Fu, P., Kawamura, K., Okuzawa, K., Aggarwal, S. G., Wang, G., Kanaya, Y., and Wang, Z.: Organic molecular composition and temporal variations of summertime mountain aerosols over 
Mt. Tai, North China Plain, J. Geophys. Res., 113, D19107, doi:10.1029/2008JD009900, 2008.

Gao, S., Hegg, D. A., Hobbs, P. V., Kirchstetter, T. W., Magi, B. I., and Sadilek, M.: Water-soluble organic components in aerosols associated with Savanna fires in Southern Africa: Identification, evolution, and distribution, J. Geophys. Res., 108(D13) 8491, doi:10.1029/2002JD002324, 2003.

Grosjean, D., Cauwenberghe, K. V., Schmid, J. P., Kelly, P. E., and Pitts Jr., J. N.: Identification of C3-C10 aliphatic dicarboxylic acids in airborne particulate matter Environ. Sci. Technol., 12, 313-317, 1978.

Herckes, P., Engling, G., Kreidenweis, S. M., and Collett Jr., J. L.: Particle size distributions of constituents during the 2002 Yosemite aerosols characterization study, Environ. Sci. Technol., 40(15), 4554-4562, 2006.

Herner, J. D., Ying, Q., Aw, J., Gao, O., Chang, D. P. Y., and Kleeman, M.: Dominant mechanisms that shape the airborne particle size and composition in central California, Aerosol Sci. Technol., 40, 827-844, 2006.

Hoffmann, D., Tilgner, A., Iinuma, Y., and Herrmann, H.: Atmospheric stability of levoglucosan: A detailed laboratory and modeling study, Environ. Sci. Technol., 44, 694-699, 2010.

Huang, X. F., Yu, J. Z., He, L. Y., and Yuan, Z.: Watersoluble organic carbon and oxalate in aerosols at a coastal urban site in China: Size distribution characteristics, sources, and formation mechanisms, J. Geophys. Res., 111, D22212, doi:10.1029/2006JD007408, 2006.

Huebert, B. J., Bates, T., Russell, P. B., Shi, G., Kim, Y. J., and Kawamura, K., Carmichael, G., and Nakajima, T.: An overview of ACE-Asia: Strategies for quantifying the relationships between Asian aerosols and their climatic impacts, J. Geophys. Res., 108(D23), 8633, doi:10.1029/2003JD003550, 2003.

Jacobson, M., Hansson, H.-C., Noone, K., and Charlson, R.: Organic atmospheric aerosols: Review and state of the science, Rev. Geophys., 38(2), 267-294, 2000.

Jaffrezo, J.-L., Aymoz, G., Delaval, C., and Cozic, J.: Seasonal variations of the water soluble organic carbon mass fraction of aerosol in two valleys of the French Alps, Atmos. Chem. Phys., 5, 2809-2821, doi:10.5194/acp-5-2809-2005, 2005.

Kanakidou, M., Seinfeld, J. H., Pandis, S. N., Barnes, I., Dentener, F. J., Facchini, M. C., Van Dingenen, R., Ervens, B., Nenes, A., Nielsen, C. J., Swietlicki, E., Putaud, J. P., Balkanski, Y., Fuzzi, S., Horth, J., Moortgat, G. K., Winterhalter, R., Myhre, C. E. L., Tsigaridis, K., Vignati, E., Stephanou, E. G., and Wilson, J.: Organic aerosol and global climate modelling: a review, Atmos. Chem. Phys., 5, 1053-1123, doi:10.5194/acp-5-1053-2005, 2005.

Kawamura, K.: Identification of $\mathrm{C}_{2}-\mathrm{C}_{10} \omega$-oxocarboxylic acids, pyruvic acid $\mathrm{C}_{2}-\mathrm{C}_{3} \alpha$-dicarbonyls in wet precipitation and aerosol samples by capillary GC and GC-MS, Anal. Chem., 65, 3505-3511, 1993.

Kawamura, K. and Kaplan, I. R.: Motor-exhaust emissions as a primary source for dicarboxylic acids in Los Angeles, Environ. Sci. Technol., 21, 105-110, 1987.

Kawamura, K. and Sakaguchi, F.: Molecular distributions of watersoluble dicarboxylic acids in marine aerosols over the Pacific Ocean including tropics, J. Geophys. Res., 104(D3), 3501-3509, 1999.

Kawamura, K. and Ikushima, K.: Seasonal change in the distribu- tion of dicarboxylic acids in the urban atmosphere, Environ. Sci. Technol., 27, 2227-2235, 1993.

Kawamura, K. and Yasui, O.: Diurnal changes in the distribution of dicarboxylic acids, ketocarboxylic acids and dicarbonyls in the urban Tokyo atmosphere, Atmos. Environ., 39, 1945-1960, 2005.

Kawamura, K. and Gagosian, R. B.: Implications of $\omega$ oxocarboxylic acids in the remote marine atmosphere for photooxidation of unsaturated fatty acids, Nature, 325, 330-332, 1987.

Kawamura, K., Kasukabe, H., and Barrie, L. A.: Source and reaction pathways of dicarboxylic acids, ketoacids and dicarbonyls in Arctic aerosols: One year of observations, Atmos. Environ., 30, 1709-1722, 1996.

Kawamura, K., Narukawa, M., Li, S. M., and Barrie, L. A.: Size distributions of dicarboxylic acids and inorganic ions in atmospheric aerosols collected during polar sunrise in the Canadian high Arctic, J. Geophys. Res., 112, D10307, doi:10.1029/2006JD008244, 2007.

Kerminen, V.-M. and Wexler, A. S.: Growth laws for atmospheric aerosol particles: an examination of the bimodality of the accumulation mode, Atmos. Environ., 29, 3263-3275, 1995.

Kerminen, V.-M., Teinilä, K., Hillamo, R. E., and Mäkelä, T.: Sizesegregated chemistry of particulate dicarboxylic acids in the Arctic atmosphere, Atmos. Environ., 33, 2089-2100, 1999.

Kleeman, M. J., Riddle, S. G., and Jakober, C. A.: Size distribution of particle-phase molecular markers during a severe winter pollution episode, Environ. Sci. Technol., 42(17), 6469-6475, 2008.

Koch, D., Bond, T. C., Streets, D., Unger, N., and van der Werf, G. R.: Global impacts of aerosols from particular source regions and sectors, J. Geophys. Res., 112, D02205, doi:10.1029/2005JD007024, 2007.

Krivácsy, Z. and Molnár, Á.: Size distribution of ions in atmospheric aerosols, Atmos. Res., 46, 279-291, 1998.

Krueger, B. J., Grassian, V. H., Cowin, J. P., and Laskin, A.: Heterogeneous chemistry of individual mineral dust particles from different dust sources regions: the importance of particle mineralogy, Atmos. Environ., 38, 6253-6261, 2004.

Lewis, D. H. and Smith, D. C.: Sugar alcohols (polyols) in fungi and green plants: 1. Distribution, physiology and metabolism, New Phytol., 66, 143-184, 1967.

Lim, H.-J., Turpin, B. J., Russell, L. M., and Bates, T. S.: Organic and elemental carbon measurements during ACE-Asia suggest a longer atmospheric lifetime for elemental carbon, Environ. Sci. Technol., 37(14), 3055-3061, 2003.

McFiggans, G., Alfarra, M. R., Allan, J. D., Bower, K. N., Coe, H., Cubison, M., Topping, D.O., Williams, P. I., Decesari, S., Facchini, M. C., and Fuzzi, S.: Simplification of the representation of the organic component of atmospheric particulates, Faraday Discuss., 130, 1-22, doi:10.1039/b419435g, 2005.

Medeiros, P. M., Conte, M. H., Weber, J.C., and Simoneit, B. R. T.: Sugars as source indicators of biogenic organic carbon in aerosols collected above the Howland Experimental Forest, Maine, Atmos. Environ., 40(9), 1694-1705, 2006.

Mochida M., Kawamura, K., Umemoto, N., Kobayashi, M., Matsunaga, S., Lim, H.-J., Turpin, B. J., Bates, T. S., and Simoneit, B. R. T.: Spatial distributions of oxygenated organic compounds (dicarboxylic acids, fatty acids, and levoglucosan) in marine aerosols over the western Pacific and off the coast of East Asia: Continental outflow of organic aerosols during 
the ACE-Asia campaign, J. Geophys. Res., 108(D23), 8638, doi:10.1029/2002JD003249, 2003.

Mochida, M. and Kawamura, K.: Hygroscopic properties of levoglucosan and related organic compounds characteristic to biomass burning aerosols particles, J. Geophys. Res., 109, D21202, doi:10.1029/2004JD004962, 2004.

Mochida, M., Umemoto, N., Kawamura, K., Lim, H.-J., and Turpin, B. J.: Bimodal size distributions of various organic acids and fatty acids in the marine atmosphere: Influence of anthropogenic aerosols, Asian dusts, and sea spray off the coast of East Asia, J. Geophys. Res., 112, D15209, doi:10.1029/2006JD007773, 2007.

Narukawa, M., Kawamura, K., Anlauf, K. G., and Barrie, L. A.: Fine and coarse modes of dicarboxylic acids in the Arctic aerosols collected during the Polar Sunrise Experiment 1997, J. Geophys. Res., 108(D18), 4575, doi:10.1029/2003JD003646, 2003.

Narukawa, M., Kawamura, K., Takeuchi, N., and Nakajima, T.: Distribution of dicarboxylic acids and carbon isotopic compositions in aerosols from 1997 Indonesian forest fires, Geophys. Res. Lett., 26, 3101-3104, 1999.

Neusüss, C., Pelzing, M., Plewka, A., and Herrmann, H.: A new analytical approach for size-resolved speciation of organic compounds in atmospheric aerosol particles: Methods and first results, J. Geophys. Res., 105(D4), 4513-4527, 2000.

Pacini, E.: From anther and pollen ripening to pollen presentation, Plant Sys. Evol., 222, 19-43, 2000.

Reid, J., Hobbs, P., Ferek, R., Blake, D., Martins, J., Dunlap, M., and Liousse, C.: Physical, chemical, and optical properties of regional hazes dominated by smoke in Brazil, J. Geophys. Res., 103(D24), 32059-32080, 1998.

Ricard, V., Jaffrezo, J.-L., Kerminen, V.-M., Hillamo, R. E., Teinilä, K., and Maenhaut, W.: Size distributions and model parameters of aerosol constituents in northern Finland during the European Arctic Aerosol Study, J. Geophys. Res., 107(D14), 4208, doi:10.1029/2001JD001130, 2002.

Russell, L. M., Hawkins, L. N., Frossard, A. A., Quinn, P. K., and Bates, T. S.: Carbohydrate-like composition submicron atmospheric particles and their production from ocean bubble bursting, Proc. National Acad. Sci., 107(15), 6652-6657, doi:10.1073/pnas.0908905107, 2010.

Satsumabayashi, H., Kurita, H., Yokouchi, Y., and Udeda, H.: Photochmeical formation of particulalate dicarboxylic acids under long-range transport in central Japan, Atmos. Environ., 24A, 1443-1450, 1990.

Schichtel B. A., Malm, W. C., Bench, G., Fallon, S., mcdade, C. E., Chow, J. C., and Watson, J. G.: Fossil and contemporary fine particulate carbon fractions at 12 rural and urban sites in the United States, J. Geophys. Res., 113, D02311, doi:10.1029/2007JD008605, 2008.

Schkolnik, G., Falkovich, A. H., Rudich, Y., Maenhaut, W., and Artaxo, P.: New analytical method for the determination of levoglucosan, polyhydroxy compounds and 2-methylerythritol and its applications to smoke and rainwater samples, Environ. Sci. Technol., 39, 2744-2752, 2005.

Shilling, J. E., King, S. M., Mochida, M., Worsnop, D. R., and Martin, S. T.: Mass spectral evidence that small changes in composition caused by oxidative aging processes alter aerosol CCN properties, J. Phys. Chem. A, 111, 3358-3368, 2007.

Simoneit, B. R. T. and Elias, V. O.: Organic tracers from biomass burning in atmospheric particulate matter over the ocean, Mar. Chem., 69(3-4), 301-312, 2000.

Simoneit, B. R. T., Schauer, J. J., Nolte, C. G., Oros, D.R., Elias, V. O., Fraser, M. P., Rogge, W. F., and Cass, G. R.: Levoglucosan, a tracer for cellulose in biomass burning and atmospheric particles, Atmos. Environ., 33(2), 173-182, 1999.

Simoneit, B. R. T., Kobayashi, M., Mochida, M., Kawamura, K., and Huebert, B.J.: Aerosol particles collected on aircraft flights over the north-western Pacific region during the ACE-Asia campaign: Composition and major sources of the organic compounds, J. Geophys. Res., 109, D19S09, doi:10.1029/2004JD004565, 2004a.

Simoneit, B. R. T., Kobayashi, M., Mochida, M., Kawamura, K., Lee, M., Lim, H.-J., Turpin, B.J., and Komazaki, Y.: Composition and major sources of organic compounds of aerosol particulate matter sampled during ACE-Asia campaign, J. Geophys. Res., 109, D19S10, doi:10.1029/2004JD004598, 2004b.

Simoneit, B. R. T., Elias, V. O., Kobayashi, M., Kawamura, K., Rushdi, A. I., Medeiros, P. M., Rogge, W. F., and Didyk, B. M.: Sugar-dominant water-soluble organic compounds in soils and characterization as tracers in atmospheric particulate matter, Environ. Sci. Technol., 38(22), 5939-5949, 2004c.

Sorooshian, A., Varutbangkul, V., Brechtel, F. J., et al.: Oxalic acid in clear and cloudy atmospheres: Analysis of data from International Consortium for Atmospheric Research on Transport and Transformation 2004, J. Geophys. Res., 111, D23S45, doi:10.1029/2005JD006880, 2006.

Venkataraman, C., Habib, G., Eiguren-Fernandez, A., Miguel, A. H., and Friedlander, S. K.: Residential biofuels in South Asia: Carbonaceous aerosol emissions and climate impacts, Science, 307, 1454-1456, 2005.

Wang, G. and Kawamura, K.: Molecular characteristics of urban organic aerosols from Nanjing: A case study of a mega-city in China, Environ. Sci. Technol., 39(19), 7430-7438, 2005.

Wang, G., Kawamura, K., Lee, S., Ho, K., and Cao, J.: Molecular, seasonal, and spatial distributions of organic aerosols from fourteen chinese cities, Environ. Sci. Technol., 40(15), 4619-4625, 2006b.

Wang, G., Kawamura, K., Watanabe, T., Lee, S., Ho, K., and Cao, J.: High loadings and source strengths of organic aerosols in China, Geophys. Res. Lett., 33, L22801, doi:10.1029/2006GL027624, 2006a.

Wang, H., Kawamura, K., and Shooter, D.: Carbonaceous and ionic components in wintertime atmospheric aerosols from two New Zealand cities: implication for solid fuel combustion, Atmos. Environ., 39, 5865-5875, 2005.

Warneck, P.: In-cloud chemistry opens pathway to the formation of oxalic acid in the marine atmosphere, Atmos. Environ., 37, 2423-2427, 2003.

Warneke, C., Bahreini, R., Brioude, J., et al.: Biomass burning in Siberia and Kazakhstan as an important source for haze over the Alaskan Arctic in April 2008, Geophys. Res. Lett., 36, L02813, doi:10.1029/2008GL036194, 2009.

Yang, L. and Yu, L. E.: Measurements of oxalic acid, oxalates, malonic acid, and malonates in atmospheric particulates, Environ. Sci. Technol., 42(24), 9268-9275, 2008.

Yao, X., Fang, M., and Chan, C. K.: Size distributions and formation of dicarboxylic acids in atmospheric particles, Atmos. Environ., 36, 2099-2107, 2002. 
Yttri, K. E., Dye, C., and Kiss, G.: Ambient aerosol concentrations of sugars and sugar-alcohols at four different sites in Norway, Atmos. Chem. Phys., 7, 4267-4279, doi:10.5194/acp-7-4267-2007, 2007.

Zhao, Y. and Gao, Y.: Mass size distributions of water-soluble inorganic and organic ions in size-segregated aerosols over metropolitan Newark in the US east coast, Atmos. Environ., 42(18), 4063-4078, 2008.
Zhuang, H., Chan, C. K., Fang, M., and Wexler, A. S.: Size distributions of particulate sulfate, nitrate and ammonium at a coastal site in Hong Kong, Atmos. Environ., 33, 843-853, 1999. 